NBER WORKING PAPER SERIES

\title{
INTERNATIONAL EQUITY TRANSACTIONS \\ AND U.S. PORTFOLIO CHOICE
}

Linda L. Tesar

Ingrid $\mathrm{M}$. Werner

Working Paper No. 4611

\section{NATIONAL BUREAU OF ECONOMIC RESEARCH 1050 Massachusetts Avenue \\ Cambridge, MA 02138 \\ January, 1994}

The authors thank Bemard Dumas, Geert Bekaert, Jeff Frankel, Danny Quah, Peter Reiss, Doug Staigerwald, and our discussants Philippe Jorion and Richard Levich for invaluable comments and suggestions. We also thank Tiff Macklem of the Bank of Canada and Hartmut Draeger of the Deutsche Bundesbank for their assistance. Richard Crabb and Jon Riddle both provided excellent research assistance. Any remaining errors are our own responsibility. This paper is part of NBER's research programs in Asset Pricing. Intemational Finance and Macrooconomics, and International Trade and Investment. Any opinions expressed are those of the authors and not those of the National Bureau of Economic Research. 


\title{
INTERNATIONAL EQUTTY TRANSACTIONS AND U.S. PORTFOLIO CHOICE
}

\begin{abstract}
This paper studies the cross-border transactions in equity by investors in Canada, Germany, Japan, the U.K. and the U.S. We find that investors from different countries make very different decisions about the allocation of their portfolio across markets. In contradiction to the notion that high variable transactions costs hinder international diversification, we find that the volume of gross equity flows vastly exceeds net equity flows and the turnover rate on foreign equity investments by some investors even exceeds domestic turnover rates. We also reject the hypothesis that U.S. investors follow the standard CAPM in allocating their global equity portfolio.
\end{abstract}

Linda L. Tesar

Economics Department

University of California at Santa Barbara

Santa Barbara, CA 93106

and NBER
Ingrid $\mathrm{M}$. Werner

Graduate School of Business

Stanford University

Stanford, CA 94305-5015

and NBER 


\section{Introduction}

The gain from diversification of investment portfolios across national markets is by now a well-established fact. Studies published in the late 1960 s and early 1970s demonstrated that investors would be rewarded for holding a global set of assets rather than skewing their portfolios toward domestic investments (see Grubel (1968), Levy and Sarnat (1970), and Solnik (1974)). Since that time, fixed barriers to international investment - such as government controls on cross-border capital flows, difficulties in obtaining information about foreign markets and differences in financial institutions - have gradually declined. However, as of 1991, the share of portfolio investment allocated to foreign assets by the United States and Canada remained at less than five percent of their total portfolios (Tesar and Werner (1993a)). Somewhat surprisingly, the turnover rate on the component of portfolios allocated to international equities is substantially larger than the turnover rate on national equity markets. This suggests that variable transactions costs are unlikely to be the main canse for home bias in portfolio allocations. Therefore models of international portfolio choice must provide explanations for both the heterogeneity in national portfolios, in particular the bias towards domestic securities, and the high volume of transactions in international securities markets.

To gain further insight into the behavior of international investors, we examine the time series patterns of bilateral equity flows between five large OECD countries; Canada, Germany, Japan, the United Kingdom, and the United States. Our study uses quarterly data drawn from Statistics Canada and the U.S. Department of the Treasury. This reasearch makes a number of contributions to the existing literature on international portfolio investment. First, our data allow us to identify the nationality of the investors involved in cross-border transactions. Thus, we are able to study potential differences in investment behavior across investors from different countries. Second, having data on bilateral securities transactions (rather than aggregate portfolio inflows and outflows) allows us to examine how each investor allocates these funds across markets. Finally, our study examines the actual portfolio choice of U.S. investors. Thus we can test models of portfolio choice directly using both the information about asset allocations and returns. Our results suggest that existing models of international portfolio choice are not supported by the data. It is our hope that these findings will help guide the development of new models of portfolio choice that are more consistent with the observed behavior of investors in international equity markets.

We summarize the rules governing U.S. reporting of international securities transactions in 
Section 2. In Section 3, we examine net equity flows reported by Canadian and U.S. reporting agencies. We find that net equity flows to and from the United Kingdom account for the majority of flows across U.S. borders, while flows to and from the United States account for most of net equity flows across Canadian borders. In a simple frictionless world, net equity flows result from changes in investors' perceptions about expected returns to, and the risk of, individual markets. If investors across countries shared the same views, one would expect net acquisitions of equity to be synchronized across investors and over markets. We find very little evidence for such a consensus among investors in the data. Perhaps even more puzzling is that net purchases are strongly positively autocorrelated suggesting that portfolios adjust sluggishly over time. This could be explained by very slow moving state variables driving the perceived investment opportunity set, or by frictions that prevent a rapid adjustment of portfolios in response to altered expectations.

In Section 4, we construct estimates of U.S. investment positions in foreign equities and foreign investment positions in U.S. equities. U.S. holdings of foreign equity have increased at a modest pace during the sample. Foreign holdings of U.S. equity exhibit a more rapid increase and reached a level of roughly 10 percent of U.S. market capitalization by the end of the sample. In section 5 , we combine these estimates of investment positions with gross transactions volumes to create a measure of turnover in foreign equity. Two basic conclusions emerge. First, gross trading volume in foreign equity is substantially larger than the corresponding net acquisitions of equity. Second, we find that the rate at which foreign investors turn over their U.S. equity portfolios is roughly at par with the average turnover rate in U.S. markets. In contrast, U.S. investors appear to be trading more frequently on their portfolio of foreign equities, particularly Japanese and British equities, than the average transactions rate on U.S. stock exchanges. U.S. turnover rates in foreign equity also tend to exceed the average turnover rates in the markets where transactions take place.

In Sections 6 and 7 , we combine our data on net purchases with excess returns to test some simple models of portfolio choice. We find that U.S. net purchases show very little significant comovement with equity returns, interest rates, dividend yields, exchange rates and measures of investor wealth. We then use our estimates of international investment positions to test whether U.S. investors allocate portfolios according to the capital asset pricing model [CAPM]. Our data strongly reject this hypothesis. 


\section{Reporting of International Securities Transactions}

Our data on equity flows are collected from Statistics Canada and the U.S. Department of the Treasury. ${ }^{1}$ Foreign direct investment activity is excluded from this data. Statistics Canada reports quarterly net transactions in foreign and domestic bonds and equities between Canadian residents and residents of the U.S., the U.K., Japan, and the EC excluding the U.K. The U.S. Treasury Bulletin reports quarterly data on purchases and sales of equities and bonds between U.S. residents and foreign residents from Canada, Germany, Japan, the U.K., and from a large number of other countries. The sample period is 1978.1-1991.3. ${ }^{2}$ Data from the U.S. Treasury appears to be the most comprehensive of the data-sets (see Tesar and Werner 1992)). Appendix A briefly summarizes the reporting requirements specified by the U.S. government. ${ }^{3}$ Reports are filed monthly with the Treasury department covering transactions with foreigners in long-term marketable securities. A foreigner is any individual, partnership, association, corporation or other organization located outside the United States.

Before going on to the analysis, we should mention some of the shortcomings of the data. First, there is no explicit penalty for failing to report securities transactions to the regulatory agencies. However, the securities brokers we have spoken with indicate that they are unlikely to "overlook" reporting requirements as they wish to stay on friendly terms with reporting agencies. In fact, they are more likely to bend over backwards to remain in compliance. Second, the rapid expansion of markets and the development of new types of financial instruments make it difficult for the reporting agencies to keep pace with the volume of flows. ${ }^{5} \mathrm{Third}$, the data may not reflect the transactions of foreign-based firms which are transacting on behalf of domestic residents. An important example are U.S. mutual funds domiciled off-shore. ${ }^{6}$ Finally, the initial deposit of ADRs and GDRs on domestic markets is reflected in the data; however, the subsequent re-issue and ultimate trading of these essentially foreign securities by domestic residents is not picked up by our data sources.

Despite these problems, the data provide a wealth of information about international portfolio investment. It is unlikely that the data reflect all cross-border securities transactions. However, as long as there is no systematic bias between the reporting of purchases and sales, and there is little reason to suspect such bias during the time period we study, our data can be interpreted as reflecting the investment choices of those in vestors who report their transactions to official agencies. As will be seen below, to the extent that gross cross-border transactions are underreported, some of the evidence on the magnitude of transactions in foreign equity and 
turnover becomes even more puzzling.

We will apply two basic concepts to the data on equity transactions. The first, net equity fows, is the change in a country's net holdings of foreing equity. We define U.S. residents' net purchases of Canadian securities as gross purchases of foreign securities from Canadian residents minus gross sales of foreign secnrities to Canadian residents. Similarly, Canadian residents' net purchases of U.S. securities are defined as the gross sales of domestic (U.S.) securities by Canadians minus the gross purchases by U.S. resident of domestic (U.S.) securities from Canadians. The second concept, gross equity flows or transactions, is the volume of crossborder equity trading. We define transactions in foreign equity by U.S. residents to be the sum of U.S. residents' purchases of foreign equity from and U.S. residents' sales of foreign equity to foreign residents. Transactions in U.S. equity by foreign residents are similarly defined.

We did some basic cross checking of the correspondence between comparable series reported by Statistics Canada and the U.S. Treasury. The reported net equity flows are significantly positively correlated. ${ }^{7}$ It does, however, appear that the average quarterly net purchases of U.S. shares reported by Statistics Canada is less than half of those reported by the U.S. Treasury. No discrepancy of similar magnitude is present for the reported U.S. net purchases of Canadian equity. ${ }^{8}$ This may reflect a tendency for Canadian investors to mis-report their purchases of U.S. equity. One might suspect that the reason is to avoid taxation or circumvent quantitative capital controls. It is of course also possible that the reporting requirements differ in the two countries. The asymmetric evidence of under-reporting however, is difficult to reconcile with such an explantion.

To facilitate comparisons between equity flows reported by the two official sources, we report all flows in millions of U.S. dollars. The Canadian data are translated into U.S. dollars using the average quarterly exchange rate drawn from the International Financial Statistics [IFS] data base. We produce descriptive statistics for real flows expressed in December 1977 prices. These are computed by deflating nominal flows using the average monthly seasonally adjusted consumer price index for each quarter from Citibase.

\section{Net Equity Flows}

\section{Net Equity Flows Crossing the U.S. Border}

Figures $1 \mathrm{a}$ and $1 \mathrm{~b}$ show net equity flows crossing U.S. borders. These flows have become more volatile after the mid 1980 s, primarily due to fluctuations in U.S. purchases of Japanese 
and British equity. Figure $1 \mathrm{~b}$ shows that the same two countries also exhibit the most volatile net purchases of U.S. equity. Note the large sale of U.S. equity by British residents during the fourth quarter of 1987 - the quarter including the stock market crash. It is interesting that investors from the other countries did not simultaneously dump U.S. stocks. We will document that such heterogeneity in investor responses across countries appears to be a characteristic of international investment behavior.

Table la shows that the United Kingdom is the most important counterpart in cross-border equity transactions with the United States. U.S. investors bought on average 169 million constant dollars worth of equity from the U.K. per quarter during the 1978.1-91.3 period. Quarterly net purchases from Canada were less than half that at $\$ 74$ million, and U.S. investors bought $\$ 27$ million of equity per quarter from Germany. While average quarterly net flows from the United States to Japan have been modest at $\$ 49$ million their volatility has been exceptionally high. The table also reports statistics on net purchases of U.S. equity by Canadian, German, Japanese, and British investors. British and Japanese investors have been the dominant foreign investors in U.S. equity, acquiring on average $\$ 235$ million (41 percent of total inflow) and $\$ 200$ million (34 percent of total inflow) respectively per quarter. Canadian investors bought on average $\$ 120$ million constant U.S. dollars of equity per quarter while German investors spent $\$ 25$ million per quarter. Note that the combined average quarterly net in vestment in U.S. equity by foreign investors of $\$ 580$ million is almost twice as large as the combined average net investment in foreign equity by U.S. investors of $\$ 319$ million. Thus, net purchases of U.S. equity by foreign residents contributed to financing the U.S. current account deficits of the 1980 s and early 1990 s.

\section{Net Equity Flows Crossing the Canadian Bonder}

Net equity flows crossing the Canadian border are illustrated in Figures 1c and 1d. Related descriptive statistics are presented in Table $1 \mathrm{~b}$. From Canada's perspective, the United States is its largest trading partner in terms of equity transactions. Canadian average net purchases of U.S. equity of $\$ 55$ million is more than twice as large as net purchases of British equity at $\$ 21$ million. U.S. investors provide 85 percent of the average equity flows to Canada. Net purchases by EC residents account for roughly 20 percent of U.S. net purchases. Note that bilateral equity flows between the United States and Canada are not only the largest in magnitude (relative to the other countries) but also exhibit the most volatility. Japanese net equity investment was modest while British investors on average withdrew funds from the Canadian equity market. Net average quarterly equity flows crossing the Canadian border were virtually balanced during this period. 


\section{Autocorrelation of Net Equity Flows}

The data on U.S. and Canadian net purchases exhibit substantial positive autocorrelation. In only one case, Canadian net purchases of EC equity, do we observe a significantly negative autocorrelation coefficient. This persistence in net purchases may be evidence that investors adjust their portfolios gradually over time. If this is indeed the case, such dynamic adjustments should be incorporated into the development and testing of models of portfolio choice.

The serial correlation of net acquisitions of equity also affects our inference based on simple correlations of net equity flows across markets. We report correlation coefficients since they have the advantage of being unit-free. However, the calculation of appropriate standard errors of the estimated correlation coefficients between time series with serial correlation is not straightforward. Instead we base our inference on the covariance between the time series and correct the corresponding standard errors for autocorrelation using a method proposed by Newey and West (1987). The method is outlined in Appendix B. Our null hypothesis is that the estimated covariances are zero, or that net equity flows are uncorrelated.

\section{Correlations of Net Equity Flows Across Markets}

In Tables $2 \mathrm{a}$ and $2 \mathrm{~b}$, we report the correjations among real net equity flows to investigate the extent to which net acquisitions of equity are synchronized across investors from different countries. Suppose that investors follow a simple mean-variance model for asset allocation, and that they for exogenous reasons start with a portfolio of primarily domestic securities. In such a world, the decision to invest in foreign equity can be prompted by an expectation that the return to foreign equity will exceed the return on domestic equity or that the inclusion of foreign equity in the portfolio will reduce risk.

To the extent that cross-border investment is driven solely by differences in expected returns, we expect to see a negative contemporaneous correlation between domestic investors' net purchases of foreign equity and foreign investors' net purchases of domestic equity. Moreover, investors would channel funds into the same "foreign" market simultaneously. If, on the other hand, cross-border investment is driven primarily by the desire to diversify across markets, the correlation between net equity purchases crossing a border from different directions might very well be positive. The diversification motive might, alternatively, make different investors target different foreign markets for their investment, which means that the cross-sectional correlations could be positive or negative.

Of course, portfolio flows between countries are part of the larger picture of trade and financial linkages that connect open economies. If equity flows are in some sense the "residual" 
component of the capital account, net equity flows may be determined by factors quite separate from the simple mean-variance trade-offs discussed above.

The first panel of Table 2a shows the correlation between quarterly net purchases of foreign equity by U.S. residents. The marginal significance levels give the probability that the estimated covariance is zero. U.S. net purchases of equity from Canadian and Japanese residents are negatively correlated, while the rest of the pair-wise correlations of net purchases are positive. In no case are the covariances significantly different from zero. Correlation of foreign investors' net purchases of U.S. equity, reported in the second panel of the table, have mixed signs but again none of the covariances are significant. Thus, there appears to be little synchronization in foreign investment in U.S. equity. The bottom panel reports the correlations between U.S. net acquisitions of foreign equity and foreign acquisitions of U.S. equity. If U.S. and Canadian investors concur, for example, that it is appropriate to reallocate the portfolio between U.S. and Canadian equity, we anticipate that the correlations will be negative. While the majority of correlations are in fact negative, none of the covariances are significantly different from zero.

A somewhat different picture emerges from the correlation between cross-border flows for Canada in Table 2b. The correlation between Canadian net purchases of foreign equity in the first panel are of mixed signs, suggesting more of a reallocation across markets rather than a general increase in Canadian holdings of all foreign equity. None of the covariances are, however, significantly different from zero. The consistently positive correlations in the second panel indicate that there appears to be a consensus among British, EC, and U.S. investors about the approporate timing of investment in Canadian equities. However, the mixed signs and the high marginal significance levels in the bottom panel suggest that Canadian investors do not agree with the investors in the other countries.

The overwhelming impression from Tables $2 \mathrm{a}$ and $2 \mathrm{~b}$ is the lack of significant correlation among net equity flows. ${ }^{9}$ Given the general nature of the alternative hypothesis and that the sample is rather limited, we do not expect to have much power against the null. The absence of comovement in net equity flows may indicate that the decisions about international portfolio choice are guided primarily by the diversification motive. This conclusion is somewhat contradicted by the high volume of cross-border investment between countries whose stock markets are highly positively correlated, i.e. Canada and the United States. Another potential explanation is that investors' strategies for portfolio allocation differ substantially across countries. Alternatively, net equity purchases may be mainly affected by more general macroeconomic conditions such as business cycle fluctuations, the differential between output growth at home 
and abroad, or fiscal policies.

\section{Cumulated Foreign Investment Positions}

In the remainder of this paper we concentrate on equity flows to and from the United States as reported by the U.S. Treasury. Using our bilateral data on net purchases of equity, we construct a quarterly time series of U.S. foreign investment positions. Such data are not available from published sources. ${ }^{10}$ The time series are interesting for two purposes. First, they provide information about the allocation of the U.S. investment portfolio across global markets. Second, the investment positions are the relevant base for thinking about turnover rates on foreign equity investments.

To create an investment position series from U.S. net purchases of equity, we cumulate net purchases starting from an initial investment position, which we take as the investment position at the end of 1977 as estimated by the Department of Commerce. At the end of 1977, the reported U.S. investment position was $\$ 4,971$ million in Canada, $\$ 350$ million in Japan, and $\$ 4,485$ million in Western Europe. We allocate the Western Europe position over Germany and the U.K. according to their relative market sizes at the end of $1977.1^{11}$ The resulting position is $\$ 1,794$ million in Germany and $\$ 2,691$ million in the United Kingdom. Starting from these intitial values, denoted $X_{0}^{i}$, the quarterly investment position is created using the following algorithm:

$$
X_{t+1}^{i}=X_{t}^{i}\left(1+R_{t+1}^{i}\right)+N P_{t, t+1}^{i},
$$

where $X_{t}^{i}$ is the U.S. investment position in market $i$ at $t, R_{t+1}^{i}$ is the gross return (including dividends) on equity in market $i$ over the quarter, and $N P_{t, t+1}^{i}$ represents quarterly net purchases of U.S. investors from market $i^{12}$ Using the data on net foreign purchases of U.S. equity, the same algorithm can be used to generate the investment position of foreign investors in the U.S. ${ }^{13}$

The resulting series for U.S. investment positions across foreign markets as a fraction of the U.S. market capitalization are plotted in Figure 2a. ${ }^{14}$ According to our estimates, the U.S. international investment position has increased from 1.3 percent of U.S. equity market capitalization in the first quarter of 1978 to 3.9 percent by the third quarter of 1991 . This increase can largely be accounted for by the growing U.S. investment position in the United Kingdom, which went from 0.3 percent in 1978.1 to 1.7 percent at the end of the sample. U.S. holdings of Canadian equity increased sharply from 0.7 in 1978.1 to 1.6 percent in the first 
quarter of 1980 , but have since fallen to a level of 1.2 percent. The U.S. investment positions in Germany and Japan have remained stable and low at around 0.5 percent thronghout the sample-period.

The investment positions of foreign investors in the United States as fractions of U.S. market capitalization are reported in Figure $2 b .^{15}$ Total foreign holdings of U.S. equity have increased steadily over the sample from a level of 4.3 percent at the outset to a level of 1.5 percent by the end of the sample. All countries have increases their investment positions in the United States, but the most dominant contributors to U.S. risk-captial were British investors whose equity holdings went from 2.1 to 5.6 percent of U.S. market capitalization over the 1978-91 period. The Japanese investment position began to rise in the mid $1980 \mathrm{~s}$ and reached a level of 1.1 percent of U.S. market caitalization by the third quarter of 1991. This late start can in part be explained by the relaxation of capital controls which took place in Japan in the mid 1980s. ${ }^{16}$ Canadians and Germans held 2.1 and 2.7 percent respectively of the U.S. equity market by the end of the sample.

Although the data display a steadily increasing level of investment in foreign equity markets by U.S. investors, the fraction of U.S. wealth allocated to foreign markets by U.S. investors is still very limited. According to our estimates, over 96 percent of U.S. wealth was invested in U.S. equity in 1991 . Home bias is still very much a feature of international equity markets.

\section{Gross Equity Flows and Turnover}

Table 3 provides descriptive statstics on gross cross-border equity trading. We report the real value of transactions by U.S. residents in Canadian, German, Japanese, and British equity as well as the value of transactions in U.S. equity by residents from Canada, Germany, Japan, and the U.K. As a benchmark, we also report the combined quarterly real trading volume in the U.S. defined as the trading volume on the American Stock Exchange, NASDAQ and the New York Stock Exchange. The first three columns report the means, standard deviations, and the coefficients of variation respectively for the entire period, 1978.1-1991.3. Results for subsamples are reported in columns four through nine.

The numbers in the first column indicate that the largest average volume of transactions is between U.S. and British citizens. The second largest volume is transactions between U.S. and Japanese citizens, followed by U.S. transactions in equity with Canadians and Germans. This ranking holds regardless of whether transactions involve U.S. or foreign equity. By comparing 
the results in Table 3 with our figures on net equity flows in Table 1a, it is clear that the gross transactions volume vastly exceeds the corresponding net transactions volume. Gross quarterly transactions range from 18 (U.S. transactions with German citizens) to 67 (U.S. transactions with Japanese citizens) times the average quarterly net bilateral equity flows. Comparing the two sub-periods, we also find a large increase in average quarterly transactions over time. Looking across U.S. residents' transactions in foreign equity, the increase is 1105 percent in British equity, 919 percent in German, 631 percent in Japanese and 85 percent in Canadian equity. Correspondingly, the quarterly level of transactions in U.S. equity went up by 2253 percent for Japanese residents, 284 percent for British, 162 percent for Canadian, and 86 percent for German residents.

The volume of gross cross-border equity trading displays considerable variation over time. In terms of volatility relative to the mean, U.S. residents' transactions in foreign equity from Germany, Japan, and the United Kingdom are each about twice as high as the volatility (compared to the mean) of their transactions in Canadian equity. An even higher volatility compared to the mean is evident in Japanese transactions in U.S. equity. Although the volatility of transactions has gone up dramatically from the earlier to the later part of the sample, the coefficients of variation for the two subsamples it have fallen in all cases except Japanese transactions in U.S. equity where the volatility almost doubled. Interestingly, the same pattern of declining coefficients of variation appears in U.S. transactions in emerging stock markets (Tesar and Werner (1993b)). The data seem to indicate that as U.S. investors increase their investment position in a particular market, their transactions volume (relative to the mean level of transactions) declines.

By cumulating the (nominal) quarterly gross cross-border transactions over each year and dividing by the estimated dollar investment position we obtain the turnover rates for crossborder equity trading. Table 4 reports the annual turnover rates (in percent) for each year from 1982 to 1990 . The first striking observation is that turnover rates for foreign investments are higher than the turnover rate in the investor's home market and the turnover rate in the market where trading takes place. Interestingly, the most extreme cases are Japanese investors' turnover rates in the U.S. equity market with an average of 334 percent and U.S. investors' turnover in Japanese equities of 377 percent. One possible explanation for these extraordinarily high numbers is that the base, or the investment position, is underestimated. However, one would have to increase the estimated positions of U.S. investors in Japan and Japanese investors in the United States six-fold to get turnover rates which are at par with the benchmarks. Also 
U.S. investors trading in British equity and Canadian investors trading in U.S. equity turn over their positions at a substantially higher rate than they do in their home markets. These turnover rates are also higher than the average turnover rates in the U.K. and the U.S. respectively. The only exception is German investors, who transact at a very modest average rate of 21 percent in the United States. Based on the last column, which gives the mean turnover rate over the entire period, it appears that U.S. investors have a larger tendency to "churn" their portfolios of foreign securities than foreign investors trading in U.S. equity. ${ }^{17}$

Another message from the table is that turnover rates vary, both across different markets and across time. For instance, the average turnover for Germany at 97 percent is substantially higher than that of the other countries. The Canadian market is at the other extreme with an average turnover rate of 20 percent. Turnover also varies over time for most markets. All markets experienced a temporary increase in turnover after the stock market crash in 1987.

The heterogeneity in turnover rates for foreign investments is most easily seen in Figures 3a and $3 \mathrm{~b}$ which illustrate U.S. investors' turnover rates in foreign equity and foreign investors' turnover rates in U.S. equity in the 1982.1-1991.3 period. Turning first to Figure 3a, we see that the U.S. investors' turnover rate on the Japanese market is substantially larger than in other markets, and that there is a large increase in the turnover rate in the 1987-90 period, followed by a sudden drop in the second quarter of 1991 . The time variation in turnover rates is even more dramatic in Figure 3b. The turnover rate on U.S. equity holdings by Japanese investors increased roughly 800 percent between 1984 and 1987, falling of suddenly in the fourth quarter of 1988 .

Several things should be kept in mind in comparing turnover rates across markets and over time. First, the numbers used in creating our measures of turnover rates may contain substantial measurement errors. Second, differences in regulations across industries and changes in regulations over time may affect where an investor chooses to conduct his or her financial transactions. This in turn may affect whether the transaction is considered a transaction with a domestic resident (in which case it will not be reported) or with a foreign resident. Finally, the transactions data include derivative securities. In periods of volatile returns in equity markets, investors may hedge their portfolios, effectively transacting several times on the same underlying investment position.

Whatever the source of the variation in turnover rates, the high volume of transactions and the high turnover rates in cross-border equity trading makes it difficult to ascribe the home bias puzzle to high variable transactions costs. The high turnover rates also give some indication 
that foreign equity investment may be dominated by institutional investors who face lower transactions costs than the average investor.

\section{What Drives U.S. Net Equity Flows?}

Even though we have seen no strong patterns of comovement between net equity flows, it is still possible that international equity purchases are sensitive to variables such as returns and risk. Table 5 reports the correlations of U.S. net purchases of equity from Canada, Germany, Japan, and the United Kingdom with four sets of financial variables. ${ }^{18}$ The marginal significance levels refer to the probability that the estimated covariances are zero.

The first set of variables are contemporaneous changes (in absolute terms) in the market capitalization of the United States and each of the foreign markets. Changes in U.S. market capitalization proxies for changes in the wealth of U.S. investors. If U.S. investors follow a strategy of holding a constant fraction of their wealth in foreign equity, an increase in wealth would be associated with increased purchases of foreign equity. Judging from the consistently positive correlations in the first row of the table, this hypothesis has some support in the data. For U.S. investment in the United Kingdom, the covariance is significantly different from zero at the ten percent level. Media tend to follow high growth markets, and to the extent that U.S. investors follow the advice of investing in such markets they would increase their equity purchases as foreign market capitalization increases. The correlation coefficients in the second row of the table are all positive, but the association is not significant.

The second set of variables is related to the returns on equity in the respective markets. Models of portfolio allocation relate investment decisions to expected returns and risk. In this simple illustration, we view the average realized monthly excess return over the quarter as a rough proxy for expected future returns. If the decision to invest in equity hinges on the investor's expectation of returns, one would expect that increases in U.S. returns should tend to decrease foreign equity purchases while increases in foreign returns should increase net equity purchases from abroad. The results show that net equity flows generally are positively correlated with both U.S. and foreign returns. U.S. purchases of equity from Japan and the United Kingdom covary positively with the return on the U.S. market. Part of the explanation for the positive correlation might be that U.S. equity returns are highly correlated with changes in U.S. wealth. Although U.S. net equity purchases are consistently positively correlated with the return on foreign markets, none of the marginal significance levels are lower than ten percent. 
To capture the impact of risk on foreign investment, we measure the correlation between net purchases and the beta of the foreign market. Beta is measured as the covariance between excess returns on the foreign market and the U.S. market divided by the variance of excess return in the U.S. market based on 60-month (5 year) rolling samples. One would expect that U.S. investors would decrease their purchases of equity from a market when that market covaries more strongly with the U.S. market. There is no evidence for such a pattern in the data.

It is often suggested by policy makers and the financial press that recent increases in capital outflows from the United States can be explained by historically low domestic interest rates. To check whether this is borne out by the data, we correlate net purchases with U.S. and foreign dividend yields and U.S. interest rates. A majority of the estimated correlations are negative, as predicted, but only in the case of U.S. investment in the United Kingdom does the marginal significance level imply that we reject the null hypothesis of no association. The correlations between U.S. net purchases and foreign yields have mixed signs. For U.S. acquisitions of Canadian equity, the association is significantly negative. We finally investigate the correlation between returns to and levels of trade-weighted and bilateral exchange rates and net equity flows. Bilateral exchange rates seem generally to be of limited importance for cross-border investment decisions. The level of the trade-weighted U.S. dollar is significantly positively related to U.S. net purchases of Canadia equity, but the value of the dollar has no significant impact on purchases of equity from other countries. ${ }^{19}$

Of the financial variables we examine, very few are significantly associated with acquisitions of foreign equity by U.S. investors. Granted, our measures of expected returns and risk are crude and might not adequately capture the importance of such variables in general for international portfolio transactions. In addition, simple correlations do not capture the investor's problem of trading off risk and return across financial assets. It is still puzzling that the data display so little systematic comovement between equity flows and simple measures of return and risk. We turn to a more explicit test of portfolio allocation in the next section.

\section{Do U.S. Investors Allocate their Portfolios According to the CAPM?}

Recent tests of international asset pricing models yield mixed results about the extent of global market integration and the validity of the CAPM in an international context (Frankel (1982), Wheatley (1988), Engel and Rodrigues (1989, 1992), Korajzyk and Viallet (1989),

Harvey (1991), Cooper and Kaplanis (1991), Ferson and Harvey (1991), Dumas and Solnik 
(1992), Heston, Rouwenhorst, and Wessels (1992), Harvey (1993)). We combine our estimates of the actual international investment positions of U.S. investors in foreign equities with data on equity returns to test whether the observed U.S. portfolio allocation satisfies the first-order conditions of maximization in a simple CAPM world. This amounts to testing whether the portfolio chosen by U.S. investors is mean-variance efficient.

Consider the set of first order conditions dictating the demand for risky assets in a standard capital asset pricing model from Merton (1973):

$$
\nu_{t+1}=\gamma \Omega x_{t},
$$

where $x_{t}$ is a vector of portfolio allocations chosen by the investor at $t, \gamma$ is the risk aversion of the investor, $\Omega$ is the covariance matrix of excess returns, and $\nu_{t+1}$ is a vector of expected excess returns between $t$ and $t+1$. When preferences are isoelastic, $\gamma$ is the coefficient of relative risk aversion and $x_{t}$ corresponds to shares of wealth.

The traditional way of implementing empirical tests of the CAPM involves aggregating similar conditions across all investors, exploiting the fact that the market portfolio equals the market-capitalization weighted average of returns to individnal equity markets. We will instead exploit our information on portfolio allocation to directly test the implications of the model on the first-order condition for maximization of one group of investors, namely U.S. residents. If the model accurately describes investment behavior, the first order conditions in equation (2) should be satisfied for each investor in international equity markets.

Our empirical implementation follows Engel and Rodrigues (1992). We assume that U.S. investors have access to a coustant riskfree rate, $r$. Let $R_{t+1}-r$ denote the realized excess return on equity. If expectations are rational, it follows that

$$
R_{t+1}-r=\nu_{t+1}+\epsilon_{t+1},
$$

where $\epsilon_{t+1}$ is a white noise error term. The first-order conditions can then be re-stated as

$$
R_{t+1}-r=\gamma \Omega x_{t}+\epsilon_{t+1}
$$

The corresponding unrestricted model is

$$
R_{t+1}-r=B x_{1}+\epsilon_{t+1},
$$

where $B$ is a matrix of regression coefficients of the same dimension as the covariance matrix. 
Under the null, the covariance matrix of the residuals, $\epsilon \epsilon^{\prime}$, is equal to the covariance matrix of excess returns, $\Omega$. Thus, the restrictions we test are that the regression coefficients in the matrix $B$ are proportional to the covariance matrix of the residuals. The unidentified constant of proportionality is equal to the coefficient of risk aversion of U.S. investors. Under the assumption that the covariance matrix is constant over time, the test involves first estimating the unrestricted systen in equation (5) using full information maximum likelihood [FIML]. The system of equations is then re-estimated, imposing the constraints implied by the model. We use a likelihood ratio test to see whether the data reject the null hypothesis that the constraints implied by the model hold. The likelihood-ratio (LR) statistic has an asymptotic $X^{2}(q)$ distribution, where $q$ is the number of restrictions imposed.

The results from FIML estimation of the system of five equations of excess returns on U.S. portfolio shares are given in Table 6. The model assumes that investors have preferences with constant relative risk aversion, and that $x_{\ell}$ corresponds to shares of wealth invested in Canada, Germany, Japan, the U.K., and the U.S. respectively. As a proxy for U.S. wealth, we use the U.S. market capitalization plus the total foreign investment posititon of U.S. investors minus the total investment position by foreign investors in the U.S. The top panel of the table reports the estimated regression coefficients and the corresponding standard erros. Few of them are significantly different from zero, which is to be expected given the well known difficulty of explaining the ex post variation in excess equity returns. The covariance matrix of the residuals is given in the lower panel in Table 6 . Covariances are multiplied by 100 . Note that there is considerable variation in the ratios of estimated coefficients, $b_{i j}$, and the elements of the covariance matrix, $s_{i j}$. Under the null-hypothesis that the model is correct, all those ratios should be equal.

It is possible to design the set of constraints of the model in several ways. In principle, the best way to test the model would be to let the constraints be $b_{i j}=\gamma s_{i j}$. Since we do not know the coefficient of risk aversion, this constraint cannot be tested without assigning an ad hoq value for $\gamma$. Alternatively, the constraint can be expressed as $b_{i j} / s_{i j}$ equal for all $i, j$. Engel and Rodrigues (1992) argue, based on results in Gregory and Veall (1985), that tests based on products rather than tests based on quotients result in more power. We follow their suggestion and specify the constraints to be of the form $b_{i j} s_{k l}=b_{k l} s_{i j}$, for all $i, j$. This leaves us with the problem of choosing the benchmark, $k, l$. We use $b_{j a p, j a p}$ and $s_{j a p, j a p}$ since both these estimated coefficients are significantly different from zero.

The log-likelihood value for the unrestricted system is 307.67 . When the twenty-four con- 
straints implied by the model are imposed, the resulting value of the log-likelihood is 284.18. Our results give a value of the LR-statistic of 46.99 which for a $X^{2}(24)$ has p-value of 0.003 . The data thus strongly reject the null hypothesis that U.S. investors follow the CAPM in their portfolio allocation. Another way of interpreting the result is that the U.S. equity investment portfolio is not mean-variance efficient.

To check the robustness of our result, we grouped countries into regions. First, we aggregated Germany and the U.K. into "Europe." This should reduce the problem of erroneously classifying trading in German securities which takes place in London as transactions in U.K. shares. Combining our new European aggregate with Canada, Japan and the U.S. implies a four-by-four system. Market capitalization-weighted return series were generated for Europe, and the U.S. investment position in Germany was added to the fraction of wealth allocated to the U.K. market. To conserve space, we do not report the estimated coefficients. The only significant parameters are in the equation for excess returns on the Japanese market; the coefficient on the Europe-weight is significantly negative, and the coefficient on the Japan-weight is significantly positive at five percent. The resulting LR-statistic was 33.43 which for a $X^{\mathbf{2}}(15)$ has a p-value of 0.004 . Finally, we also considered North America (Canada and the U.S.) as one region. If Canadian residents are in fact conducting many of their transactions in New York, it may be that little information is lost in the aggregation. Again, the estimated coefficients of the resulting three-by-three system are not reported to conserve space. All three coefficients in the equation for excess returns in Japan are significant but none of the other estimated parameters are significant. The LR-statistic was in this case 26.52 which for a $X^{2}(8)$ has a p-value of 0.001 .

The null hypothesis that U.S. investors follow the simple CAPM in allocating their investment portfolio is thus strongly rejected by the data. Even if we try to reduce potential reporting problems by aggregating markets into regions, we still strongly reject. Engel and Rodrigues (1992) were not able to reject that the market-capitalization-weighted portfolio was mean-variance-efficient using monthly data on market capitalizations and excess returns from ten countries. Beyond the differences in data frequency and sample countries, a possible explanation for our stronger result is that we study the investment behavior of one particular group of investors whereas Engel and Rodrigues capture the behavior of the marginal investor in each market, wherever that investor may reside. 


\section{Conclusion}

In this paper we examine cross-border equity flows in Canada, Germany, Japan, the U.K. and the U.S. To our knowledge, this is among the first studies to combine information about the return to equity investment with the actual portfolio allocations of international investors. In many respect, our results are negative. Observed adjustments in international portfolios are not consistent with the first-order conditions of the CAPM. Neither do investors across countries seem to behave in unison; country- and investor-specific factors seem to play an important role in portfolio allocations. Net equity flows to and from the U.K. account for the majority of all flows across U.S. borders. Flows to and from the U.K. account for most of the flows across Canadian borders. Finally, U.S. residents appear to churn their holdings of foreign assets, while the turnover rate on foreign holdings of U.S. equities is more closely in line with the average turnover rate on the U.S. market. We conclude that there is a considerable amount of heterogeneity in international investment behavior.

The data strongly rejects that U.S. investors' port folios are mean-variance efficient. Previous studies have had only limited success in rejecting the CAPM on international data. This highlights the difference between the norm in the finance literature which involves basing tests solely on relationships among rates of return as opposed to testing the actual portfolio allocation strategies of invstors. When trying to understand international portfolio choice, research should focus on combining the price data with the actual portfolio investment made by international investors. To facilitate this task, it is imperative that researchers obtain more detailed data on international securities transactions.

One possible explanation for our failure to confirm even the most basic predictions of simple models of portfolio choice is that cross-border equity flows are underreported to official agencies, and therefore our data are not representative of investor behavior. This may indeed be the case; however, equity investment by the countries included in our sample now account for over 10 percent of all transactions on U.S. stock exchanges. If these data are to be considered suspect, one has to question the validity of any analysis using balance of payments data. It is possible that reporting problems make it difficult to find linkages between returns and portfolio allocations. Given that the results are robust to aggregating across regions, which should reduce such problems, the evidence seems more convincing.

Another possibility is that existing models of portfolio allocation can be thought of as descriptions of "mature" investors making marginal changes in an already well-diversified portfolio. As of the 1990 s, national portfolios remained strongly biased toward domestic securities. 
The problem facing investors is how to move their existing holding of equity toward a better diversified portfolio, while still remaining sensitive to high frequency changes in returns. Thus, our research points to the need for new models of portfolio choice which can explain the dynamics of portfolio adjustment. 


\section{Endnotes}

1. Data on corporate and government bonds are available from the same source.

2. The Deutsche Bundesbank reports quarterly purchases and sales of equities and bonds between German residents and residents of Canada, Japan, the U.K., the U.S., and a broad set of other countries. We excluded the German data from our analysis to conserve space. We have not been able to find similar bilateral data on international portfolio transactions for the United Kingdom and Japan.

3. This is extracted from the Instructions for Preparation of Monthly Form S, International Capital Form S, Department of the Treasury, Office of the Assistant Secretary for Economic Policy, OMB No. 1505-0001. We do not have access to the corresponding documentation for Canada. Discussions with representatives from the Bank of Canada lead us to believe that the reporting requirements in Canada are similar.

4. Note that the data refiect the residency of the party involved in the transaction and not the country of origin of the security itself.

5. See Stekler and Truman (1992) for a complete description of the problems involved in collecting data on portfolio flows.

6. It is our understanding that in 1992, the U.S. began collecting data on off-shore U.S. brokerages.

7. The correlation between U.S. net purchases of Canadian equity reported by the two data sources is 0.853 . The correlation between reports of Canadian net purchases of U.S. equity is somewhat smaller at 0.518 .

8. Tesar and Werner (1992) show that the Canadian equity-investment position in the U.S. reported by Statistics Canada is considerably smaller than the Canadian investment position reported by the U.S. Treasury.

9. In examining the correlations between U.S. net purchases of equity from nineteen countries, including 15 emerging stock markets, Tesar and Werner (1993b) also find little or no correlation between net purchases from different markets. 
10. The Department of Commerce only reports the investment position on an annual basis for a limited number of countries. Their series is constructed in a way similar to the method we propose below.

11: According to Morgan Stanley Capital International the market capitalization of Germany was $\$ 65.1$ billion, and of the United Kingdom was $\$ 96.4$ billion in the fourth quarter of 1977. We apply the weights of 40 percent and 60 percent to German and the United Kingdom respectively for the intitial values of our Western Europe aggregate.

12. Gross returns are calculated using stock market indices from Morgan Stanley Capital International.

13. As initial values, we use the reported foreign investment positions (assuming a 60-40 split between the U.K. and Germany); Canada \$5,671 million, Japan $\$ 594$ million, Germany $\$ 17,083$, and the U.K. $\$ 11,389$.

14. Our estimates of the U.S. investment position are slightly lower than those reported by the Department of Commerce. At the end of 1990, they estimate the foreign investment position in Canada and Western Europe combined to be $\$ 86,510$ million. Our estimate is $\$ 85,907$ million. The Department of Commerce stopped reporting the U.S. investment position in Japan in 1987 since they perceived the position to be grossly underestimated.

15. Our estimated investment positions of foreign investors in the United States are larger than those reported by the Department of Commerce. They estimate the total foreign investment position by these countries at the end of 1990 to be $\$ 188_{r} 967$ million. Our estimate is substantially larger at $\$ 256,004$ million. This is a bit surprising since our algorithm tends to bias the estimated position downwards by not crediting capital gains to equity acquired during the quarter of purchase. On the other hand, we assume that all dividends from foreign equity investment are reinvested, which may make the investment position too large.

16. See Riddle (1992) for a discussion of capital controls in the five countries in our sample.

17. Tesar and Werner (1993a) discusses the high turnover rate on foreign equity holdings in more detail.

18. We use the following data sources. Data on market capitalization, equity returns, and dividend yields are calculated from the stock market indices published by Morgan Stanley 
Capital International. Treasury Bill returns are from CRSP and exchange rates from Citibase.

19. Froot and Stein (1991) find no significant relationship between the value of the dollar and aggregate portfolio inflows. 


\section{References}

Adler, M., and B. Dumas, 1983, International Portfolio Choice and Corporation Finance: A Synthesis, Journal of Finance 38, 925-984.

Cooper, I.A., and E. Kaplanis, 1991, What Explains The Home Bias in Portfolio Investment?, (London Business School).

Dumas, B., and B. Solnik, 1992, The World Price of Exchange Rate Risk, Working Paper (H.E.C. School of Management).

Dumas, B., 1993, Partial Equilibrium cs. General-Equilibrium Models of International Capital Market Equilibrium, Wharton School Working Paper No. 93-1.

Engel, C.M. and A.P. Rodrigues, 1989, Tests of International CAPM with Time- Varying Covariances, Journal of Applied Econometrics 4, 119-138.

Engel, C.M. and A.P. Rodrigues, 1992, Tests of Mean-Variance Efficiency of International Equity Markets, Working Paper (University of Washington).

Ferson, W.E., and C.R. Harvey, 1991, The Risk and Predictability of International Equity Returns, Working Paper (University of Chicago).

French, K., and J. Poterba, 1991, Investor Diversification and International Equity Markets, The American Economic Review, 222-226.

Frankel, J., 1982, In Search of the Exchange Risk Premium: A Six-Currency Test Assuming Mean-Variance Optimization, Journal of International Money and Finance 1, 255-74.

Froot, K.A., and J.C. Stein, 1991, Exchange Rates and Foreign Direct Investment: An Imperfect Capital Markets Approach, The Quarterly Journal of Economics, November, 11911217.

Gergory, A., and M. Veall, 1985, Formulating Wald Tests of Nonlinear Restrictions, Econometrica 6, 1465-1468.

Grubel, H.G., 1968, Internationally Diversified Portfolios, The American Economic Review $58,1299-1314$.

Harvey, C.R., 1991, The World Price of Covariance Risk, The Journal of Finance 41, 111-157. 
Harvey, C.R., 1993, Predictable Risk and Returns in Emerging Markets, Working Paper (Duke University).

Heston, S.L., K.G. Rouwenhorst, and R.E. Wessels, 1992, The Structure of International Stock Returns, Working Paper (Yale University).

Korajczyk, and Viallet, 1989, An Empirical Investigation of International Asset Pricing, The Review of Financial Studies 2, 553-585.

Levy, H., and M. Sarnat, 1970, International Diversification of Investment Portfolios, The American Economic Review 50, 668-675.

Merton, R.E., 1973, An Intertemporal Capital Asset Pricing Model, Econometrica 41, 867-887.

Newey, W. and K. West, 1987, A Simple Positive Semi-Definite Heteroscedasticity and Autocorrelation Consistent Covariance Matrix, Econometrica 55, 703-708.

Riddle, J., 1992, Controls on International Securities Transactions, Working Paper (University of California, Santa Barbara).

Solnik, B.H., 1974, Why Not Diversify Internationally Rather than Domestically?, Financial Analysts Journal 30, 91-135.

Stekler, L. and E.M. Truman, 1992, The Adequacy of the Data on U.S. International Financial Transactions: A Federal Reserve Perspective, International Finance Discussion Papers, Board of Governors No. 430.

Tesar, L.L., and I.M. Werner, 1992, Home Bias and the Globalization of Securities Markets, NBER Working Paper No. 4218.

Tesar, L.L., and I.M. Werner, 1993a, Home Bias and High Turnover, Working Paper, (Stanford Business School).

Tesar, L.L., and I.M. Werner, 1993b, U.S. Equity Investment in Emerging Stock Markets, to appear in Portfolio Investment in Developing Countries, the World Bank.

Wheatley, S., 1988, Some Tests of International Equity Integration, The Journal of Financial Economics 21, 177-212. 


\section{Appendix A:}

\section{U.S. Reporting of International Securities Transactions}

Each month, all transactions between U.S. and foreign residents in long-term marketable securities must be recorded on a form ("International Capital Form $\mathrm{S}^{n}$ ) which is then filed with the Treasury department. Reporting is required by law for "all banks, other depositary institutions ..., International Banking Facilities (IBFs), bank holding companies, brokers, dealers, nonbanking enterprises or other persons in the United States ..., who on their own behalf, or on behalf of customers, engage in transaction in long-term securiteis DIRECTLY with for eigners..." (Instructions, p. 1). Reports are also required by brokers and institutions who intermediate transactions between a domestic client (private investors or another broker or dealer) and a foreigner. A foreigner is any individual, partnership, association, corporation or other organization located outside the United States. Under these guidelines, branches of American brokers and dealers located in foreign countries are considered foreigners. Exemption from reporting is granted when the grand total of purchases or sales of all long-term securities fall below $\$ 2$ million during the reporting month.

The definition of long-term marketable securities include public and private issues of debt and equity with maturity of more than one year from date of issue. It includes "common and preferred stocks or investment company shares, rights, scrip, bonds, debentures, Floating Rate Notes (FRNs), Continually-Offered Medium Term Notes, Collateralized Mortgage Obligations (CMOs), zero-coupon bonds and notes, equipment trust certificates and similar long-term marketable corporate debt instruments issued by entitites located in the United States or in a foreing country; marketable long-term debt obligations of the U.S. Treasury, Federal Financing Bank, United States Government-owned corporations, and Federally-sponsored agencies; and marketable long-term obligations of state and local government or of governments of foreign countries, including any agencies, corporations financial institutions, or other instrumentalities thereof." It also includes "American Depository Receipts (ADRs), when issued by, or surrendered to, Depositories of ADRs; options and warrants to purchase and/or sell long-term securities and certificates or receipts representing an interest in particular coupon of principal payments of marketable U.S. Treasury securities" (Instructions, p. 4). Reports cover new security issues, direct placements, and securities issued under Shelf Registration provisions. The rule is that the geographic location of the issuing entity determines the classification of a security as domestic or foreign. Thus, equity issued by a U.S. subsidiary (branch or agency) of a foreign-based firm is considered domestic equity. 
Transactions with foreigners in options and warrants should be reported regardless of the maturity of the option and warrant (Instructions, p. 4). When options and warrants are issued by an entity other than the issuer of the underlying security, the option and warrant is classified according to the location of its own issuer. Form $S$ gives the following exampe: "a dealer located in New York writes put/call warants on a British stock, e.g. British Telecom, and selle the warrants to foreigners. The sale of the warrants should be reported as purchases by foreigners of a domestic corporate bond. At the time the warrants are exercised, the transactions would be recorded as a purchase/sale, as appropriate, of foreign stock to which the warrants applied" (Instructions, p. 5). Options and warrants are bundled with the underlying class of securities, i.e. corporate equity, corporate bonds, marketable Treasury \& Federal Financing Bank bonds \& notes, and Bonds of U.S. Government corporations and federally sponsored agencies in the aggregated data. 
Appendix B:

Calculating Robust Standard Errors of Covariances

Although our sample is rather short, we rely on asymptotic theory to derive the formula for robust standard errors of covariances. If $x_{t}$ and $y_{t}$ denote the de-meaned time series, and we define $z_{t}$ to be the product of these series, $x_{t} y_{t}$, then

$$
\sqrt{T}\left[\frac{1}{T} \sum_{t=1}^{T} z_{t}\right] \rightarrow N\left(E_{t}\left(x_{t} y_{t}\right), V\right),
$$

where $V=\lim _{T \rightarrow \infty} \operatorname{Var}\left(\frac{1}{\sqrt{T}} \sum_{t=1}^{T} z_{t}\right)$. We estimate $V$ as

$$
\hat{V}_{T}=\frac{1}{T} \sum_{t=1}^{T}\left(\left(z_{t}-\bar{z}_{T}\right)^{2}+2 \sum_{i=1}^{k(l)} W_{T}(l)\left(z_{t}-\bar{z}_{T}\right)\left(z_{t-i}-\bar{z}_{T}\right)\right),
$$

where $\bar{z}_{T} \equiv \frac{1}{T} \sum_{t=1}^{T} z_{t}, k(l)$ is of order $T^{1 / 4}$, and $W_{T}(l)=\left[1-\frac{1}{T+1}\right]$. Our time series have 55 observations, and we use 6 lags in estimating $\hat{V}\left(2 \cdot(55)^{1 / 4}\right)$. Under the null that the series are uncorrelated, $\bar{z}_{T} \equiv 0$. We thus set this to zero in the formula for calculating $\hat{V}$. The random variable $\left[\sqrt{T} \frac{\text { Cov }}{\sqrt{\hat{v}}}\right]$ has a standard normal distribution, $N(0,1)$, under the null hypothesis. The reported marginal significant levels refer to this distribution. 


\section{List of Tables}

Table 1a Net Equity Flows Crossing the U.S. Border 1978.1-1991.3

Table 1b Net Equity Flows Crossing the Canadian Border 1978.1-1991.3

Table 2a Correlations: Net Equity Flows Crossing the U.S. Border 1978.1-1991.3

Table 2b Correlations: Net Equity Flows Crossing the Canadian Border 1978.1-1991.3

Table 3 Gross Cross-Border Equity Trading 1978.1-1991.3

Table 4 Turnover in Cross-Border Equity Trading (percent)

Table 5 Correlations of net U.S. Equity Flows and Financial Variables 1978.1-1991.3

Table 6 Regressions of Excess Returns on U.S. Portfolio Shares 
Table 1a Net Equity Flows Crossing the U.S. Border 1978.1-1991.3

\begin{tabular}{|c|c|c|c|c|c|c|c|c|c|}
\hline $\begin{array}{c}\text { Variable } \\
\text { (b) }\end{array}$ & Moan & $\begin{array}{c}\text { Standard } \\
\text { Dentation }\end{array}$ & Max & Min & $\begin{array}{c}\text { AR(1) } \\
\text { (a) }\end{array}$ & $\begin{array}{c}\text { AR(2) } \\
\text { (a) }\end{array}$ & $\begin{array}{c}\text { AR(3) } \\
\text { (a) }\end{array}$ & $\begin{array}{c}\text { AR(4) } \\
\text { (a) }\end{array}$ & $\begin{array}{c}\text { LJung-Box(4) } \\
\text { p-value }\end{array}$ \\
\hline
\end{tabular}

U.S. purchases of foreign equity

$\begin{array}{lrrrrrrrrr}\text { CANADA } & 74.0 & 163.8 & 503.3 & -254.4 & 0.54^{\star} & 0.20 & -0.06 & -0.15 & 0.000 \\ \text { GERMANY } & 26.8 & 113.0 & 439.2 & -311.4 & 0.39^{\star} & -0.04 & -0.05 & 0.14 & 0.038 \\ \text { JAPAN } & 48.6 & 592.3 & 2415.3 & -1486.9 & 0.32^{\star} & 0.32^{\star} & 0.25 & 0.04 & 0.004 \\ \text { U.K. } & 169.4 & 370.8 & 1678.6 & -461.3 & 0.27 & -0.09 & -0.00 & 0.13 & 0.238\end{array}$

Foreign purchases of U.S. equhy

\begin{tabular}{lrrrrrrrrr} 
CANADA & 120.3 & 161.9 & 553.1 & -364.1 & $0.43^{*}$ & $0.28^{\star}$ & -0.05 & -0.29 & 0.000 \\
GERMANY & 25.0 & 131.9 & 450.4 & -208.7 & $0.45^{*}$ & 0.10 & -0.12 & -0.13 & 0.007 \\
JAPAN & 200.1 & 540.5 & 2256.0 & -796.5 & $0.54^{\star}$ & $0.28^{\star}$ & $0.28^{*}$ & 0.20 & 0.000 \\
U.K. & 234.8 & 585.4 & 1347.3 & -2692.1 & 0.25 & 0.10 & -0.21 & 0.17 & 0.072 \\
\hline
\end{tabular}

Source: U.S. Treasury Bulletin Units: Million U.S. dollar $(1977=100)$

(a) An asterisk indicates significance at the five percent level.

(b) Nominal purchases are defiated using the average quarterly Consumer Price Index from Citibase $(1977=100)$. 
Table 1b Net Equity Flows Crossing the Canadlan Border 1978.1-1991.3

\begin{tabular}{|c|c|c|c|c|c|c|c|c|c|}
\hline $\begin{array}{c}\text { Variable } \\
\text { (a) }\end{array}$ & Mean & $\begin{array}{l}\text { Standerd } \\
\text { Doviation }\end{array}$ & Max & Min & $\begin{array}{c}\text { AR(1) } \\
\text { (b) }\end{array}$ & $\begin{array}{c}\text { AR(2) } \\
\text { (b) }\end{array}$ & $\begin{array}{c}\text { AR(3) } \\
\text { (b) }\end{array}$ & $\begin{array}{c}\text { AR(a) } \\
\text { (b) }\end{array}$ & $\begin{array}{c}\text { Lump-box(4) } \\
\text { p-value }\end{array}$ \\
\hline \multicolumn{10}{|c|}{ Canadian purcases of forelgn equity } \\
\hline EC ex. U.K. & 3.5 & 10.3 & 46.6 & -30.0 & $-0.30 *$ & 0.16 & -0.02 & 0.13 & 0.098 \\
\hline JAPAN & 0.9 & 23.2 & 105.1 & -43.5 & 0.14 & 0.26 & 0.02 & -0.18 & 0.128 \\
\hline U.K. & 21.3 & 36.2 & 127.3 & -40.3 & $0.49^{*}$ & $0.39^{*}$ & 0.32 & $0.38^{*}$ & 0.004 \\
\hline U.S. & 54.5 & 160.9 & 726.7 & -307.7 & -0.14 & -0.02 & -0.00 & -0.09 & 0.238 \\
\hline \multicolumn{10}{|c|}{ Foreign purchases of Canadian equity } \\
\hline EC ex. U.K. & 12.3 & 45.3 & 240.8 & -58.1 & $0.56^{\star}$ & 0.23 & 0.09 & -0.02 & 0.789 \\
\hline JAPAN & 1.6 & 16.5 & 74.9 & -52.8 & $0.30^{*}$ & 0.10 & 0.02 & 0.05 & 0.190 \\
\hline U.K. & -2.1 & 51.0 & 169.7 & -100.0 & $0.39^{\star}$ & 0.06 & -0.22 & -0.15 & 0.010 \\
\hline U.S. & 67.6 & 257.2 & 752.8 & .394 .5 & $0.48^{\circ}$ & 0.22 & -0.15 & -0.24 & 0.000 \\
\hline
\end{tabular}

Source: Statistics Canada

Units: Million U.S. dollars $(1977=100)$

(a) Nominal purchases are translated into U.S. dollars using the average quarterly exchange rate from Cltibase. Dollar purchases are deflated using the average quarterly Consumer Price Index from Citibase (1977=100).

(b) An asterisk indicates significance at the five percent level. 
Table 2a Correlations: Net Equity Flows Crossing the U.S. Border 1978.1-1991.3

corr. MSL (a) corr. MSL (a) corr. MSL (a)

U.S. purchases of equity from:

\begin{tabular}{llllllll}
\multicolumn{2}{l}{ GERMANY } & \multicolumn{2}{c}{ JAPAN } & \multicolumn{3}{l}{ U.K. } \\
CANADA & \multirow{2}{*}{0.00} & 1.00 & -0.19 & 0.16 & 0.19 & 0.16 \\
GEAMANY & & & 0.35 & 0.15 & 0.04 & 0.39 \\
JAPAN & & & & & & 0.23 & 0.49
\end{tabular}

Purchases of U.S. equity by:

\begin{tabular}{|c|c|c|c|c|c|c|}
\hline \multirow[b]{2}{*}{ CANADA } & \multicolumn{2}{|c|}{ GERMANY } & \multicolumn{2}{|c|}{ JAPAN } & \multicolumn{2}{|l|}{ U.K. } \\
\hline & 0.02 & 0.87 & -0.05 & 0.64 & -0.18 & 0.15 \\
\hline GERMANY & & & -0.14 & 0.20 & 0.20 & 0.27 \\
\hline JAPAN & & & & & 0.20 & 0.15 \\
\hline
\end{tabular}

Investor agreement between the U.S. and:

\begin{tabular}{llllllll}
$\begin{array}{l}\text { CANADA } \\
\text { corr. }\end{array}$ & MSL (a) & \multicolumn{2}{l}{ GERMANY } & \multicolumn{2}{l}{ JAPAN } & \multicolumn{3}{l}{ U.K. } \\
& corr. & MSL (a) & corr. & MSL (a) & corr. & MSL (a) \\
-0.315 & 0.188 & -0.13 & 0.23 & -0.37 & 0.25 & 0.15 & 0.23
\end{tabular}

Source: U.S. Treasury Bulletin

Units: Million U.S. dollars $(1977=100)$

(a) The Marginal Significance Level gives the probability under the null that the covariance is zero. 
Table 2b Correlations: Net Equlty Flows Crossing the Canadian Border 1978.1-1991.3

\begin{tabular}{|c|c|c|c|c|c|c|c|}
\hline & & corr. & $M S L$ (a) & com. & $M S L$ (a) & cort. & MSL (a) \\
\hline \multicolumn{8}{|c|}{ Canadian purchases of equity from: } \\
\hline & & JAPAN & & U.K. & & U.S. & \\
\hline EC ex. U.K. & & -0.26 & 0.46 & 0.16 & 0.44 & -0.02 & 0.93 \\
\hline JAPAN & & & & -0.41 & 0.14 & -0.06 & 0.27 \\
\hline U.K. & & & & & & 0.04 & 0.48 \\
\hline \multicolumn{8}{|c|}{ Purchases of Canadian equity by: } \\
\hline & & JAPAN & & U.K. & & u.s. & \\
\hline EC ex. U.K. & & 0.11 & 0.40 & 0.59 & 0.24 & 0.44 & 0.18 \\
\hline JAPAN & & & & 0.09 & 0.57 & 0.12 & 0.51 \\
\hline U.K. & & & & & & 0.44 & 0.35 \\
\hline \multicolumn{8}{|c|}{ Investor aggrement betwen Canada and: } \\
\hline $\begin{array}{l}\text { EC ex. U.K. } \\
\text { cor. }\end{array}$ & $M S L$ (a) & $\begin{array}{l}\text { JAPAN } \\
\text { corr. }\end{array}$ & MSL (a) & $\begin{array}{l}\text { U.K. } \\
\text { corr. }\end{array}$ & $M S L(a)$ & $\begin{array}{l}\text { U.S. } \\
\text { corr. }\end{array}$ & MSL (a) \\
\hline 0.062 & 0.542 & -0.06 & 0.67 & 0.09 & 0.67 & -0.24 & 0.23 \\
\hline
\end{tabular}

Source: Statistics Canada

Units: Million U.S. dollars $(1977=100)$

(a) The Marginal Significance Lovel gives the probability under the null that the covariance is zero. 
Table 3 Groes Crose-Border Equlty Trading 1978.1-1991.3

\begin{tabular}{|c|c|c|c|c|c|c|c|c|c|}
\hline & \multicolumn{3}{|c|}{ 1978.1-1991.3 (55 obo.) } & \multicolumn{3}{|c|}{ 1978.1-1984.4 (28 obs.) } & \multicolumn{3}{|c|}{ 1985.1-1991.3 (27 obs.) } \\
\hline & Moan & $\begin{array}{l}\text { Standerd } \\
\text { Dowiation }\end{array}$ & $\begin{array}{l}\text { std. Dow.t } \\
\text { Moan }\end{array}$ & Mean & $\begin{array}{l}\text { Standard } \\
\text { Dewiation }\end{array}$ & $\begin{array}{c}\text { Std. Dow. } / \\
\text { Mean }\end{array}$ & Moan & $\begin{array}{l}\text { Standerd } \\
\text { Devlation }\end{array}$ & $\begin{array}{l}\text { Std. Dov. } \\
\text { Mean }\end{array}$ \\
\hline
\end{tabular}

Real Tramections by U.S.

Reoldents In Equily from (a)

$\begin{array}{lrrrrrrrrr}\text { CANADA } & 1097 & 528 & 0.46 & 774 & 314 & 0.40 & 1432 & 496 & 0.35 \\ \text { GERMANY } & 495 & 536 & 1.08 & 90 & 58 & 0.65 & 916 & 483 & 0.53 \\ \text { JAPAN } & 3239 & 3009 & 0.93 & 790 & 421 & 0.53 & 5778 & 2338 & 0.40 \\ \text { U.K. } & 4067 & 4251 & 1.05 & 633 & 335 & 0.53 & 7628 & 3398 & 0.45\end{array}$

Real Traracections in U.S.

Equitly by Realdents trom (a)

\begin{tabular}{|c|c|c|c|c|c|c|c|c|c|}
\hline CANADA & 3399 & 1810 & 0.53 & 1895 & 651 & 0.34 & 4960 & 1183 & 0.24 \\
\hline GERMANY & 1187 & 529 & 0.45 & 834 & 300 & 0.36 & 1553 & 460 & 0.30 \\
\hline JAPAN & 3918 & 5227 & 1.33 & 325 & 152 & 0.47 & 7645 & 5328 & 0.70 \\
\hline U.K. & 6555 & 4457 & 0.68 & 2740 & 1257 & 0.46 & 10512 & 2771 & 0.26 \\
\hline \multicolumn{10}{|c|}{ Total Real Transectione } \\
\hline In U.S. equithy (a) & 170311 & 85071 & 0.50 & 98480 & 37123 & 0.38 & 244801 & 47757 & 0.20 \\
\hline
\end{tabular}

Source: U.S. Treasury Bulletn

Unita: Million U.S. dollar $(1977-100)$

(a) Nominal grose flows are deflated using the average quarterty Consumer Price Index from Clabase. 
Table 4 Tumover In Croes-Border Equlty Trading (porcent)

\begin{tabular}{|c|c|c|c|c|c|c|c|c|c|c|}
\hline Turnover & 1982 & 1983 & 1984 & 1985 & 1986 & 1987 & 1988 & 1989 & 1990 & meen \\
\hline U.S. markel (a) & 44 & 48 & 48 & 55 & 65 & 03 & 56 & 53 & 40 & 57 \\
\hline Candians in U.S (b) & 86 & 98 & 89 & 89 & 103 & 122 & 85 & 88 & 69 & 92 \\
\hline Gemans in U.S (b) & 17 & 28 & 22 & 17 & 21 & 29 & 20 & 23 & 17 & 21 \\
\hline Japanese in U.S. (b) & 161 & 229 & 151 & 348 & 502 & 656 & 513 & 228 & 198 & 334 \\
\hline Britsh in U.S. (b) & 49 & 54 & 49 & 53 & 65 & 87 & 65 & 67 & 60 & 61 \\
\hline Foreigners in U.S. (b) & 49 & 57 & 51 & 55 & 73 & 117 & 98 & 75 & 65 & 71 \\
\hline Canadien marker (a) & 14 & 17 & 15 & 20 & 11 & 35 & 24 & 25 & 23 & 20 \\
\hline Amerlcans in Canada (b) & 28 & 33 & 29 & 38 & 47 & 60 & 33 & 29 & 26 & 36 \\
\hline Germen marker (a) & 24 & 44 & 42 & 54 & 72 & 270 & 151 & 100 & 07 & 97 \\
\hline Americana In Germany (b) & 27 & 51 & 33 & 47 & 74 & 105 & 69 & 72 & 105 & 65 \\
\hline Japanese markef (a) & 35 & 127 & 35 & 36 & 28 & 75 & 60 & 03 & 40 & 50 \\
\hline Americano In Japan (b) & 298 & 272 & 257 & 244 & 254 & 405 & 450 & 556 & 654 & 377 \\
\hline U.K. makkel (a) & 31 & 30 & 37 & 38 & 57 & 107 & 06 & 4 & 42 & 51 \\
\hline Americans In U.K. (b) & 72 & 96 & 97 & 109 & 182 & 235 & 174 & 209 & 193 & 152 \\
\hline Americane abroad (b) & 61 & 75 & 76 & 87 & 129 & 181 & 150 & 170 & 165 & 122 \\
\hline
\end{tabular}

(a) From 'Anatomy of World Markota;' 1991, Goldman Sachs investment Research, Table 1.18. p.17.

(b) Authon' eatimates based on groate traneactions as reported by the U.S. Treatury and authors' own estimates of investment positions based on cumulated nol purchases of euqity. Wo take the annual averages of our estimated investmen1 positions as the base and the annual transactions volume to be the quartorly transactions cumulated over the year. 
Table 5

Corrolatlona of Net U.S. Equity Flows and FInanclal Varlables 1978.1-1991.3

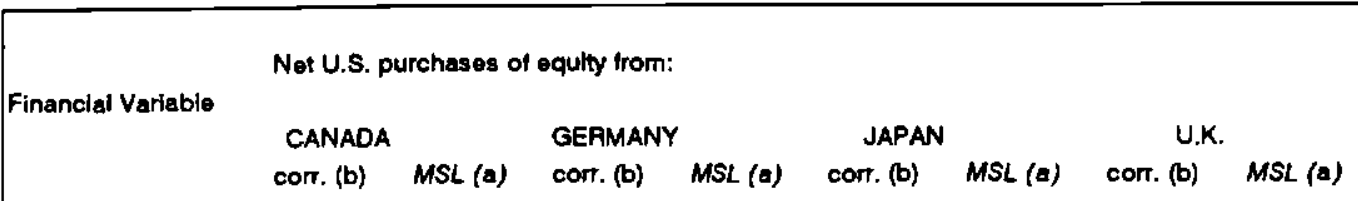

Changes in market capitallzation:

$\begin{array}{lllllllll}\text { U.S.A. } & 0.30 & 0.21 & 0.21 & 0.16 & 0.46 & 0.11 & 0.23 & 0.10 \\ \text { Foreign } & 0.32 & 0.17 & 0.45 & 0.15 & 0.218 & 0.30 & 0.17 & 0.15\end{array}$

Average equity returns and betas with U.S. marker:

$\begin{array}{lllllllll}\text { U.S. rotum } & 0.30 & 0.19 & 0.14 & 0.17 & \underline{0.33} & 0.08 & \underline{0.17} & 0.00 \\ \text { Forelgn retum } & 0.26 & 0.15 & 0.37 & 0.11 & 0.20 & 0.16 & 0.09 & 0.24 \\ \text { Forelgn beta (c) } & -0.12 & 0.17 & 0.29 & 0.23 & 0.12 & 0.41 & 0.04 & 0.89\end{array}$

Average olvidend yields and interest retes:

$\begin{array}{lllllllll}\text { U.S. yleld } & -0.27 & 0.13 & -0.20 & 0.41 & -0.06 & 0.83 & \underline{-0.45 *} & 0.03 \\ \text { Forelgn yield } & \underline{-0.40} & 0.09 & -0.08 & 0.33 & 0.01 & 0.97 & 0.10 & 0.51 \\ \text { 30-day U.S. T.b.HI } & -0.27 & 0.25 & -0.10 & 0.63 & -0.04 & 0.88 & -0.26 & 0.15 \\ \text { 90-day U.S. T-bill } & -0.31 & 0.20 & -0.11 & 0.49 & -0.04 & 0.85 & -0.24 & 0.10\end{array}$

Average exchange rate: (d)

(1) Aeturns

\begin{tabular}{|c|c|c|c|c|c|c|c|c|}
\hline Trade-welghted & -0.36 & 0.12 & 0.09 & 0.47 & 0.15 & 0.26 & 0.14 & 0.42 \\
\hline Bilateral & -0.07 & 0.42 & 0.06 & 0.62 & 0.01 & 0.87 & -0.15 & 0.41 \\
\hline \multicolumn{9}{|l|}{ (ii) Levels } \\
\hline Trade-welghted & $\underline{0.07}$ & 0.01 & -0.06 & 0.71 & -0.11 & 0.52 & -0.04 & 0.69 \\
\hline Bilateral & $\overline{0.31}$ & 0.23 & -0.11 & 0.61 & -0.07 & 0.79 & -0.22 & 0.17 \\
\hline
\end{tabular}

Sources: Net purchases of equity come trom the U.S. Treasury Bulletin. Stock market returns, dlvidend yieids. and market capltalizations come fom Morgan Stanely Capltal International. T-bill returns are from CASP and exchange rates from Citibase

(a) The Marginal Slgnificance Level gives the probability under the null that the covariance is 20 ro.

(b) An asterisk (underilned coefficlent) indicates that the covariance is slgnificantly diflerent from zero at flve (ten) percent.

(c) Authors' estimates of beta defined as the covarience of the retum on the forelgn market with the U.S. market. divided by the varlance of the return to the U.S. market. Estimates are made on rolling $60-$ month samples of excess returns using data trom Morgan Staniey Capital international and CRSP.

(d) Note that the U.K. exchange rate la expressed as U.S. dollars per Pound. 
Table 6 Regressions of Excess Returns on U.S. Portiolio Shares.

\begin{tabular}{|c|c|c|c|c|c|}
\hline $\begin{array}{l}\text { Investment } \\
\text { position } \\
\text { Equation }\end{array}$ & $\begin{array}{c}\text { CANADA } \\
\text { (standard error) }\end{array}$ & $\begin{array}{c}\text { GEAMANY } \\
\text { (standard error) }\end{array}$ & $\begin{array}{c}\text { JAPAN } \\
\text { (standard error) }\end{array}$ & $\begin{array}{c}\text { U.K. } \\
\text { (standard error) }\end{array}$ & $\begin{array}{c}\text { U.S. } \\
\text { (standard error) }\end{array}$ \\
\hline \multicolumn{6}{|c|}{ Estimated coefficients: (a) } \\
\hline \multirow[t]{2}{*}{ CANADA } & 10.053 & 15.200 & 4.343 & -8.184 & -0.085 \\
\hline & $(27.479)$ & $(62.609)$ & $(27.563)$ & $(20.403)$ & $(0.318)$ \\
\hline \multirow[t]{2}{*}{ GERMANY } & -0.986 & 56.412 & 21.987 & -16.519 & -0.051 \\
\hline & $(53.261)$ & $(67.497)$ & (27.972) & $(28.770)$ & $(0.507)$ \\
\hline \multirow[t]{2}{*}{ JAPAN } & -2.947 & 35.781 & $59.197^{\circ}$ & $\underline{-27.294}$ & 0.035 \\
\hline & $(25.905)$ & (34.962) & (24.152) & $(15.009)$ & $(0.248)$ \\
\hline \multirow[t]{2}{*}{ U.K. } & 1.482 & 23.405 & 6.471 & -5.787 & -0.025 \\
\hline & (18.945) & $(70.488)$ & $(36.440)$ & $(26.984)$ & $(0.249)$ \\
\hline \multirow[t]{2}{*}{ U.S. } & -2.204 & -5.556 & 10.472 & -0.955 & 0.039 \\
\hline & (32.846) & (๒3.131) & $(27.948)$ & $(28.127)$ & $(0.337)$ \\
\hline \multicolumn{6}{|c|}{ Covariance matrix of residuais $(\times 100)$ : } \\
\hline CANADA & 1.039 & 0.198 & 0.323 & 0.590 & 0.604 \\
\hline GERMANY & & 1.104 & 0.245 & 0.408 & 0.306 \\
\hline JAPAN & & & 0.815 & 0.423 & 0.295 \\
\hline U.K. & & & & 0.893 & 0.438 \\
\hline U.S. & & & & & 0.692 \\
\hline Log-likelihood: & 307.67 & & & & \\
\hline
\end{tabular}

Specification: $R(t+1)-r=B^{*} x(t)+e(t+1)$

Sources: The intitial investment position was taken from the Department of Commerce. Survey of Current Business. We used net equity flows reported in the U.S.I Treasury Bulletin to create the quarterly investment positions of U.S. investors. The U.S. market capitalization as well as returns on equity indices came Irom Morgan Stanely Capital Intemational. T-bill returns are from CRSP.

(a) An asterisk (underlined coefficient) indicates significance at the five (ten) percent level. 
Figure Legends

Figure 1a Net U.S. Purchases of Foreign Equity Source: U.S. Treasury Bulletin $(1977=100)$.

Figure $1 \mathrm{~b}$ Net Foreign Purchases of U.S. Equity Source: U.S. Treasury Bulletin $(1977=100)$.

Figure 1c Net Canadian Purchases of Foreign Equity Source: Statistics Canada $(1977=100)$.

Figure 1d Net Foreign Purchases of Canadian Equity Source: Statistics Canada $(1977=100)$.

Figure 2a U.S. Equity Investment Position in Foreign Equity

Note: U.S. equity investment position as a fraction of U.S. market capitalization.

Figure 2b Foreign Equity Investment Position in U.S. Equity

Note: Foreign equity in vestment position as a fraction of U.S. market capitalization.

Figure 3a U.S. Investors' Turnover Rates in Foreign Equity

Note: Transactions divided by the investment position.

Figure 3b Foreign Investors' Turnover Rates in U.S. Equity

Note: Transactions divided by the investment position. 


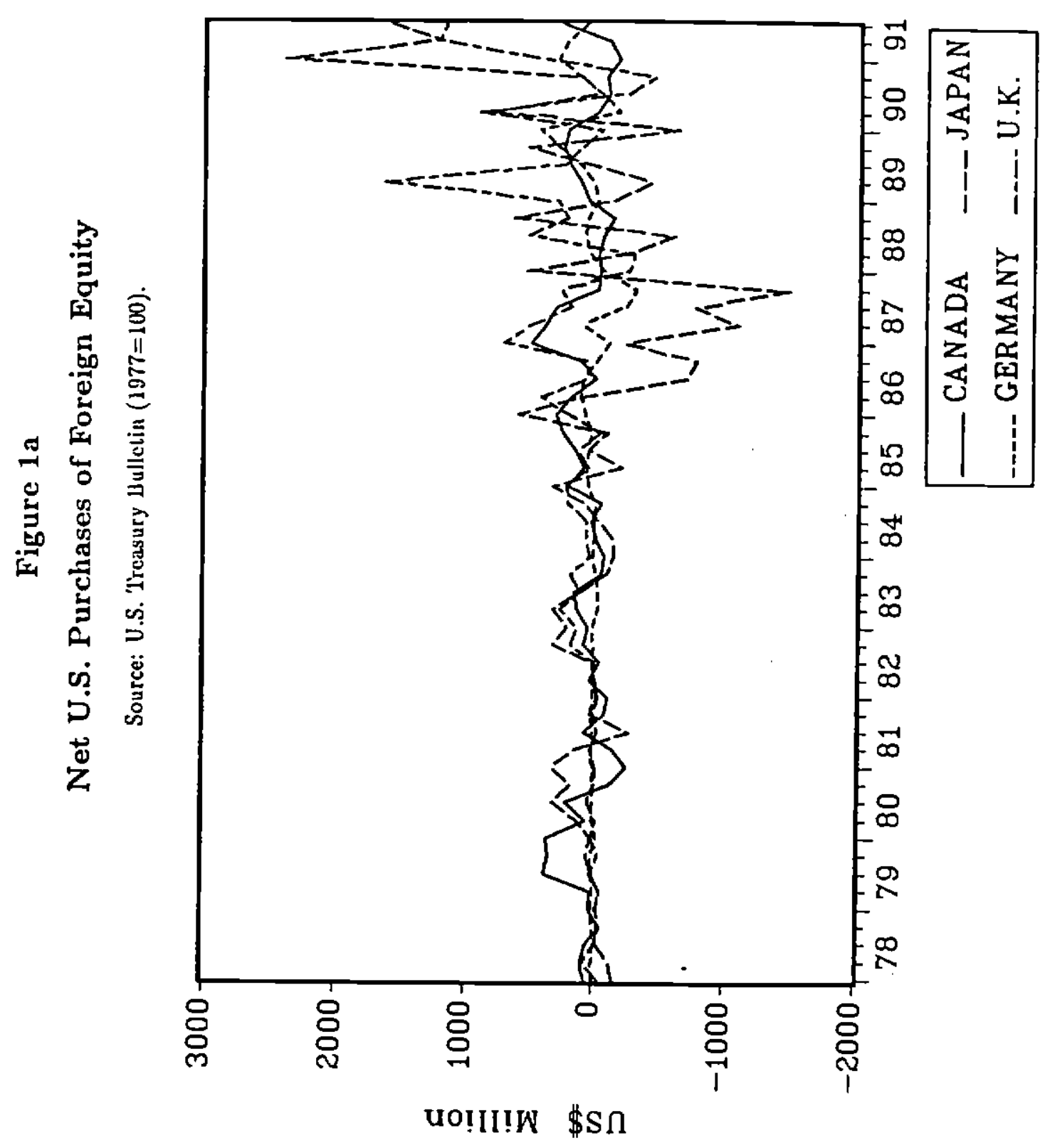




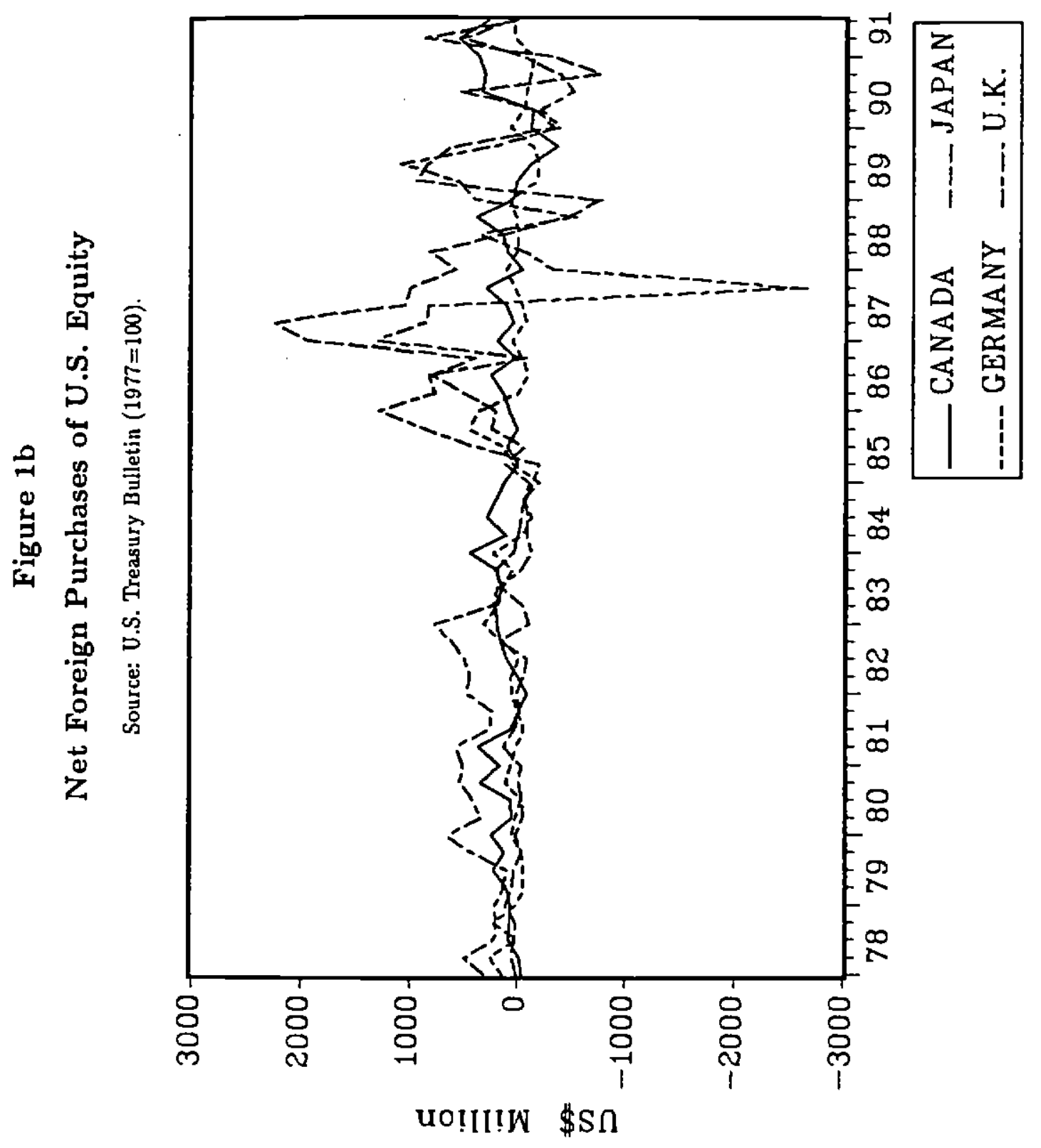




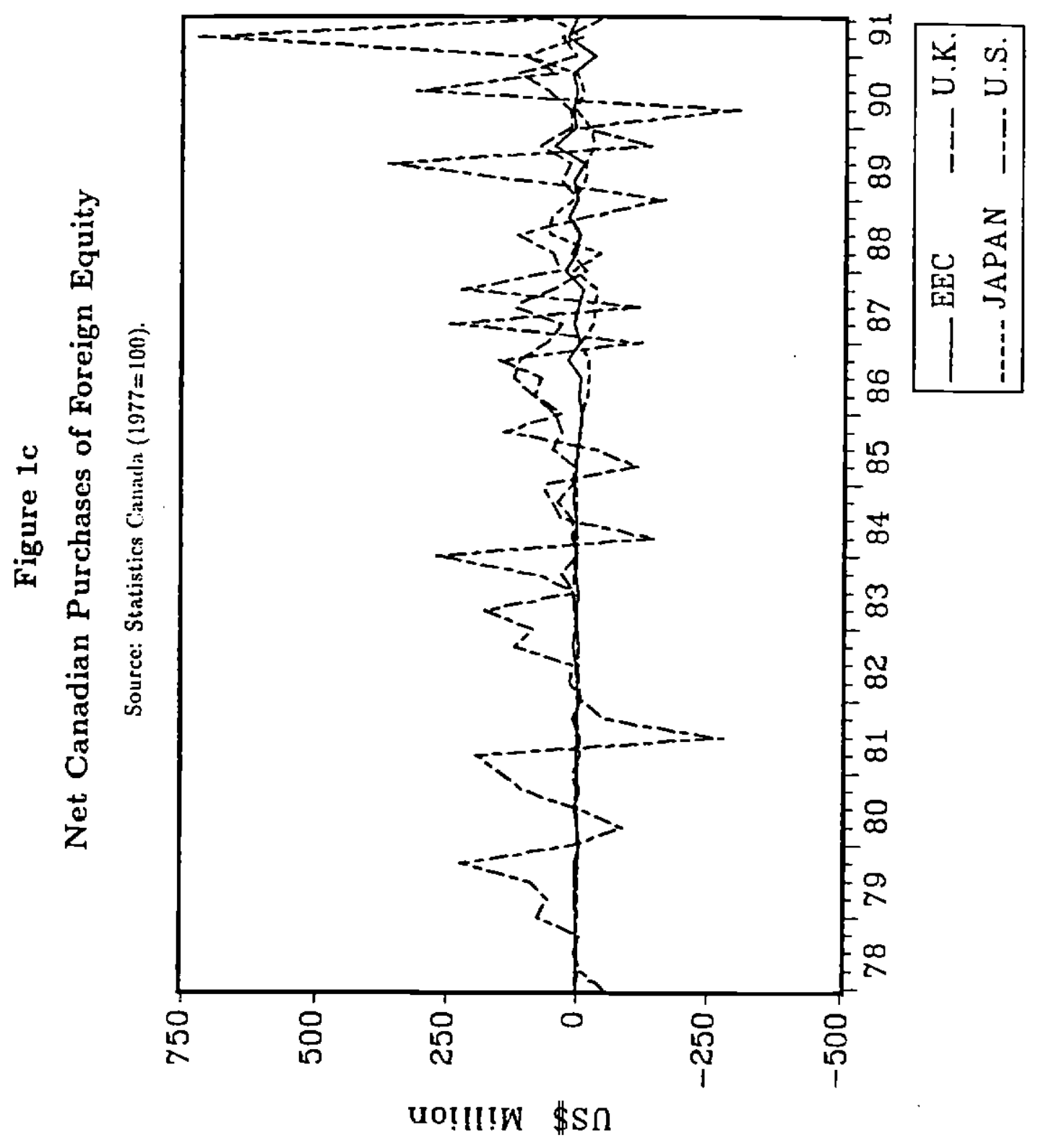




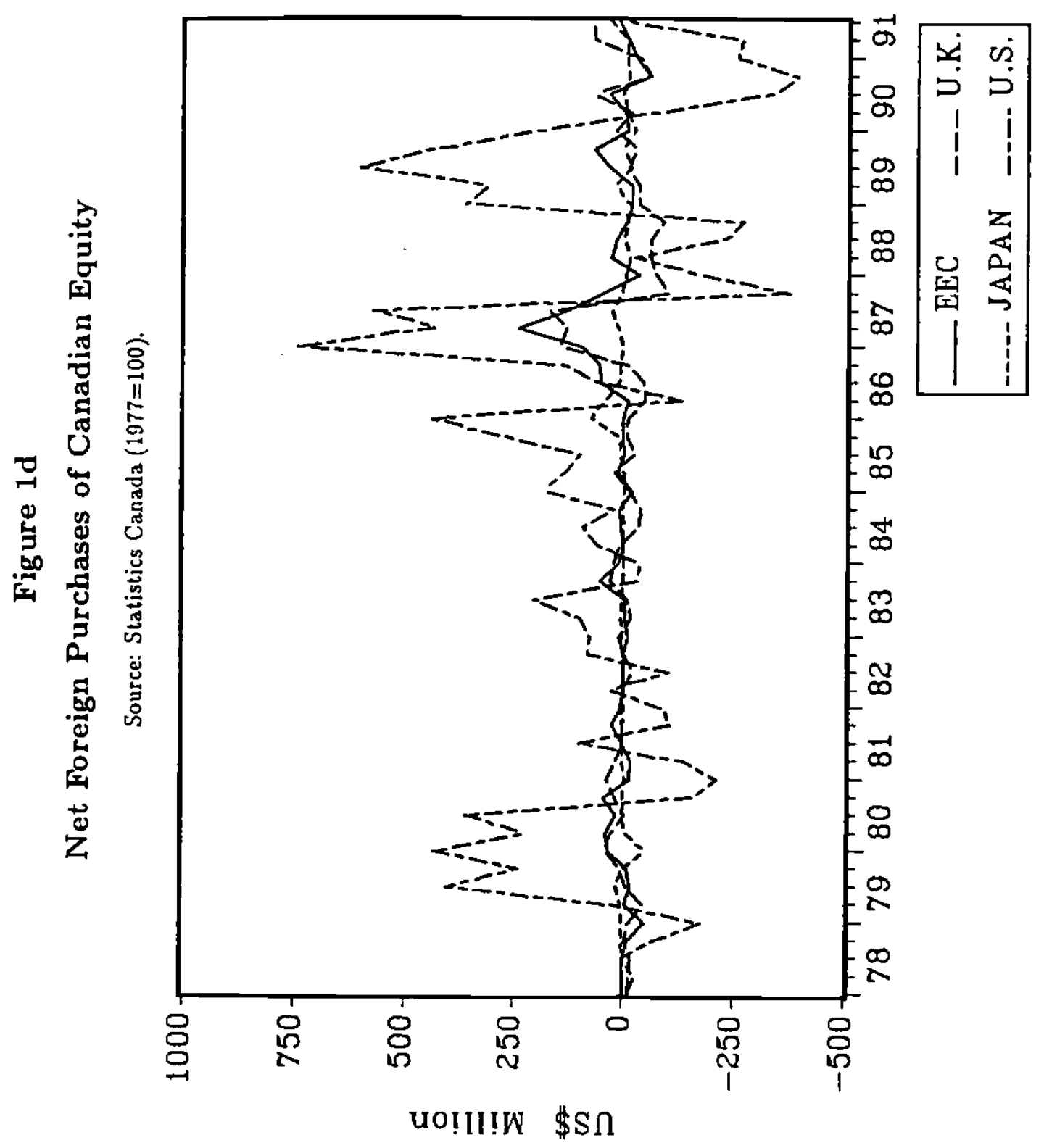




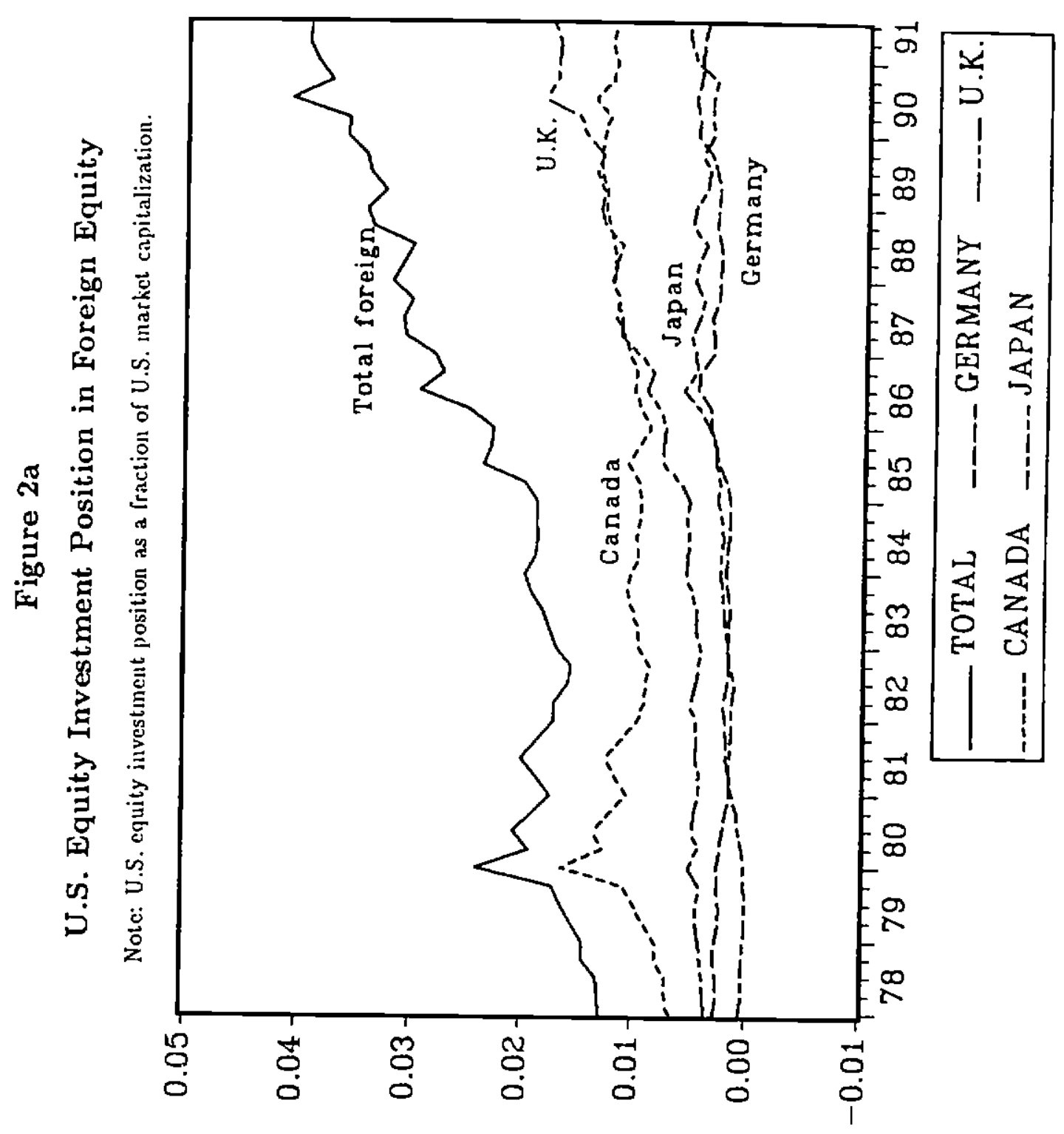




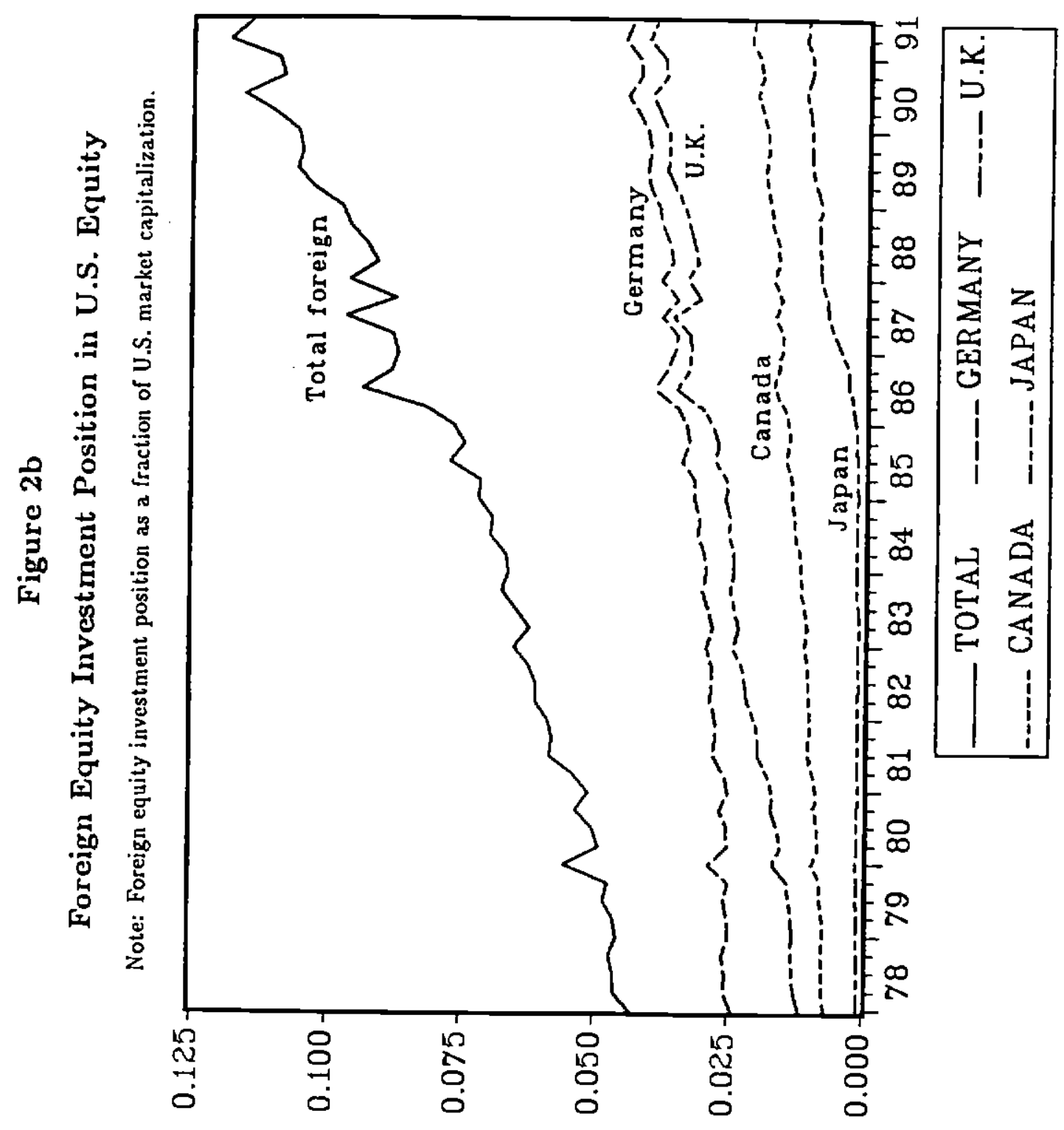




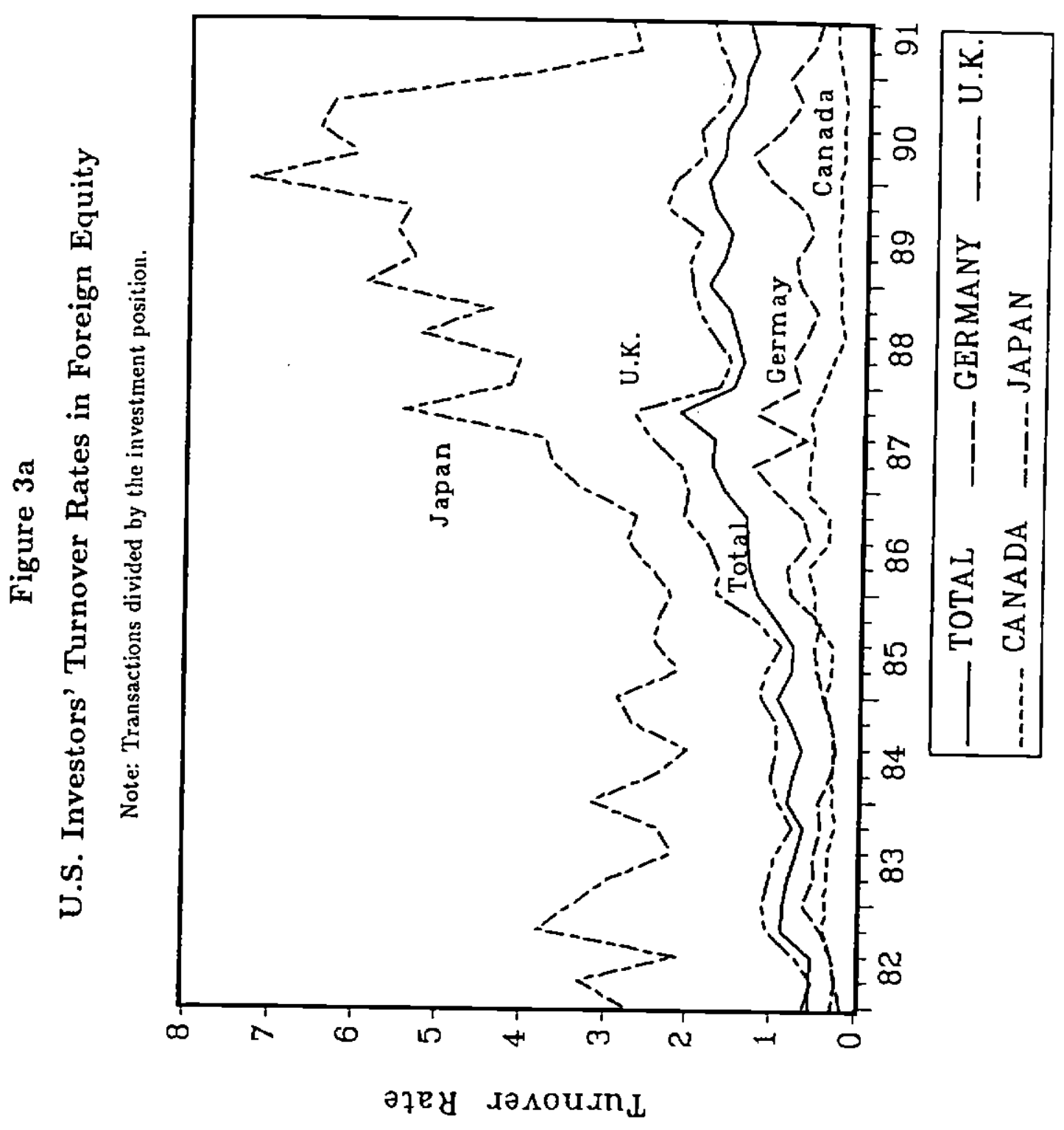




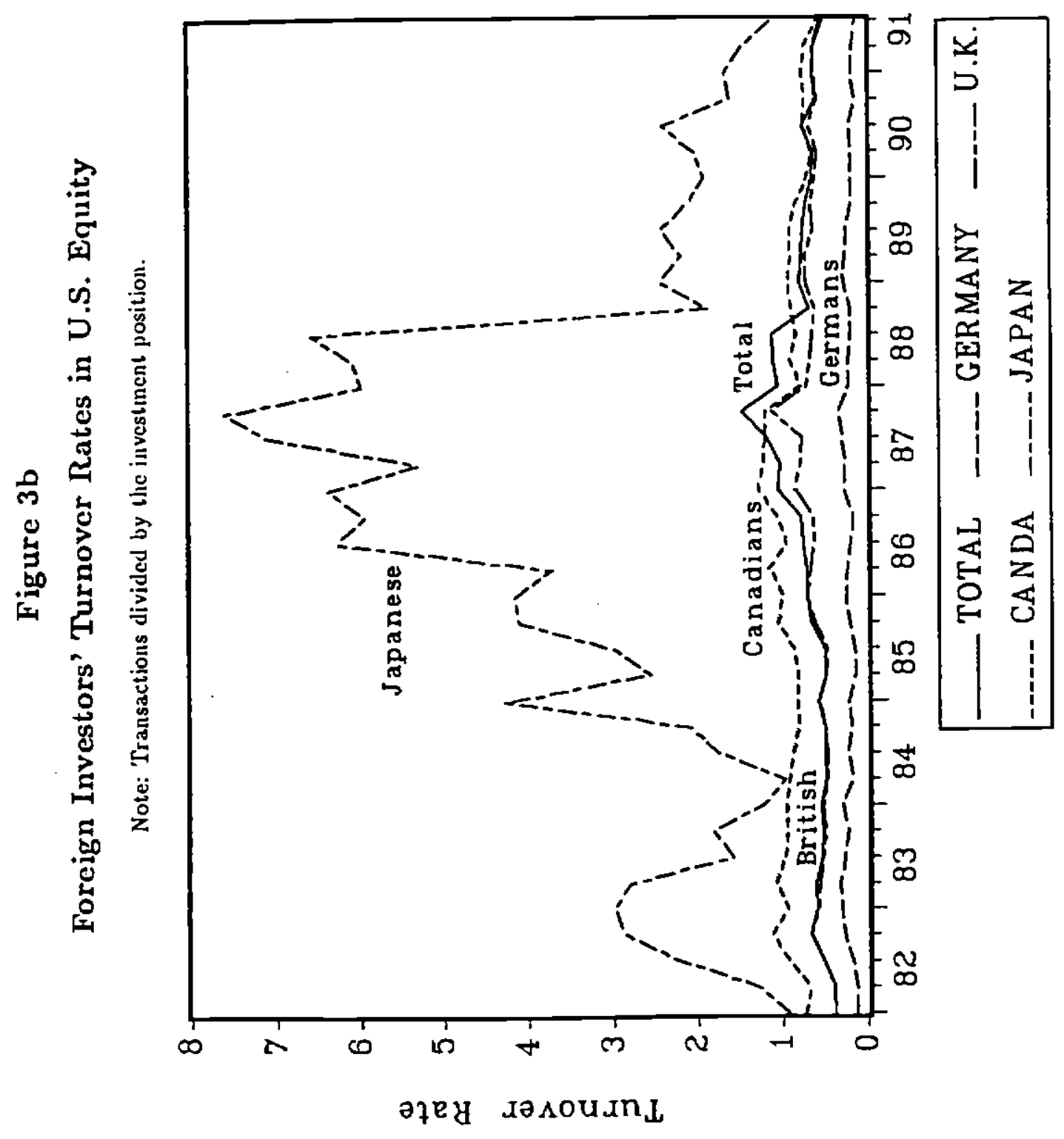

